\title{
Olhares e perspectivas que fabricam a diversidade do passado e do presente: por uma arqueologia etnográfica das bacias dos rios Trombetas e Nhamundá
}

Glances and perspectives that fabricate the past and the present diversity: An ethnographic archeology of the Trombetas and Nhamundá river basins

\section{Ruben Caixeta de Queiroz}

\section{OpenEdition}

Journals

Edição electrónica

URL: http://journals.openedition.org/aa/1285

DOI: $10.4000 /$ aa. 1285

ISSN: 2357-738X

\section{Editora}

Programa de Pós-Graduação em Antropologia Social (UnB)

\section{Edição impressa}

Data de publição: 1 dezembro 2014

Paginação: 161-200

ISSN: 0102-4302

\section{Refêrencia eletrónica}

Ruben Caixeta de Queiroz, «Olhares e perspectivas que fabricam a diversidade do passado e do presente: por uma arqueologia etnográfica das bacias dos rios Trombetas e Nhamundá», Anuário Antropológico [Online], v.39 n.2 | 2014, posto online no dia 01 agosto 2017, consultado o 28 abril 2021. URL: http://journals.openedition.org/aa/1285 ; DOl: https://doi.org/10.4000/aa.1285 


\section{Olhares e perspectivas que fabricam a diversidade do passado e do presente: por uma arqueologia etnográfica das bacias dos rios Trombetas e Nhamundá.}

Ruben Caixeta de Queiroz

UFMG

A barca de pedra está lá, e a proa é alta e aguda como na primeira noite, Pedro Orce não estranha, cada um de nós vê o mundo com os olhos que tem, e os olhos vêem o que querem, os olhos fazem a diversidade do mundo, e fabricam as maravilhas, ainda que sejam de pedra, e as altas proas, ainda que sejam de ilusão.

(José Saramago, Jangada de Pedra)

\section{Introdução: (des)articulações entre antropologia e arqueologia}

O presente artigo é o desdobramento do paper que apresentamos durante o seminário Aprofundando a Amazônia: Contribuições da Arqueologia à Etnologia, realizado no dia 30 de novembro de 2012 na Universidade de Brasília. Especialmente, é uma tentativa de responder a uma provocação proferida nesse mesmo seminário por um dos mais importantes arqueólogos atuantes no Brasil, André Prous, e, ao mesmo tempo, de lançar considerações a respeito das possíveis colaborações entre arqueólogos e etnólogos nos estudos sobre populações atuais e antigas na Amazônia e alhures.

Tal provocação foi feita logo após nossa apresentação numa mesa da qual também participaram, além do professor André Prous, o arqueólogo Eduardo Góes Neves, que tem produzido um dos trabalhos mais profícuos no momento atual no que tange às articulações entre arqueologia e etnologia na Amazônia. Resumindo o teor da provocação: o etnólogo não pode esperar uma contribuição do arqueólogo para demonstrar a continuidade entre certa população indígena, ocupando um determinado território na atualidade, e uma população que ocupou aquele mesmo território num passado mais distante, digamos, 500 anos antes da chegada do homem europeu. Tal provocação visava, no meu entender, nos alertar sobre o uso político (e, muitas vezes, bem-intencionado) da arqueologia pelos antropólogos na elaboração de relatórios de identificação de terras indígenas e na demonstração da ocupação tradicional e do direito originário de 
determinado povo sobre determinado território. Essa afirmação se baseia num dado aparentemente simples e lugar-comum: o fato de que, antes e depois da colonização, os grupos indígenas sempre estiveram num movimento de deslocamento territorial e de dispersão, isso valendo tanto para as sociedades caçadoras coletoras quanto para as agricultoras.

Aliás, essa foi a preocupação de Curt Nimuendaju, na década de 1940, quando elaborou o Mapa Etno-Histórico e quis dar conta de tal mobilidade indígena na apresentação de dados geográficos e linguísticos dos povos das terras baixas da América do Sul. A dificuldade de mostrar a continuidade entre passado e presente desses povos é ainda mais gigante se pensarmos que, de um lado, a colonização produziu fraturas radicais na maior parte desses povos (ou grupos étnicos, ou sociedades), devido às guerras, às epidemias ou à migração forçada; e, de outro lado, nunca soubemos exatamente onde começam e onde terminam essas "unidades" étnicas ou "sociedades", seja no passado, seja no presente. ${ }^{2}$

Não creio que a afirmação do professor André Prous esteja fundada numa situação concreta, de um caso no qual tal uso da arqueologia tenha sido feito pelo perito da etnologia, mas numa "intuição" de como é ou poderia ser usada a arqueologia pela etnologia. Penso ainda que o professor André Prous estivesse, implicitamente, nos alertando sobre as dificuldades de trabalho enfrentadas numa pesquisa conjunta (envolvendo um grupo de etnólogos e arqueólogos) dirigida pelo próprio André Prous e por nós mesmos na calha do Rio Trombetas: trata-se do "Projeto Norte Amazônico: etnologia e arqueologia na calha do Rio Trombetas e na região das Guianas (por uma abordagem integrada entre os sistemas sociocósmicos do presente e os vestígios materiais do passado)". De forma paralela a esse projeto, coordeno um grupo de trabalho para identificação e delimitação da Terra Indígena Kaxuyana-Tunayana, numa área que coincide em parte com aquela abrangida pelo projeto de pesquisa citado acima. Ora, supõe-se que os indígenas esperassem uma contrapartida das pesquisas científicas propriamente ditas com aquelas voltadas para o reconhecimento de seu território, sobretudo se levarmos em conta que tais pesquisas estavam em curso no mesmo período.

Além do mais, considero muito razoável ou legítimo que os indígenas residentes ali atualmente tenham tentado, por mera curiosidade ou por interesse político, estabelecer uma relação de continuidade entre as formas de produção material e cultural dos moradores mais antigos (seus possíveis antepassados, quaisquer que tenham sido suas origens étnicas ou linguísticas) daquele território (vestígios materializados nas terras pretas, nas cerâmicas, nos machados de pedra, nos raladores de mandioca, nos fusos, nos petroglifos) e a população 
indígena atualmente ali residente. $\mathrm{O}$ ato de descobrir tais artefatos, olhá-los, separá-los, seja isso feito por um índio ou por um arqueólogo, necessariamente torna-se ressignificação. Isso não quer dizer que tudo seja ressignificação e que tudo seja da mesma ordem de sentidos, nem que os diferentes sentidos tenham equivalência.

Dito de outra forma, os processos de observação e de ressignificação assinalados acima (do arqueólogo-etnólogo e do indígena) seguem métodos distintos, objetivos diferentes, mas nem por isso um é mais objetivo do que o outro: os dois são invenções e reinvenções de fases ou tradições ou de culturas, na direção do que já assinalou Roy Wagner (1981). Da mesma forma que nada nos garante uma conexão imediata entre o "presente etnográfico" de um povo indígena habitante de um determinado território e o povo que habitou aquele mesmo território no passado mais longínquo (digamos, de mil anos), nada nos autoriza a chegar à conclusão imediata de que o tempo de larga escala é suficiente para interromper qualquer ligação entre esses dois grupos humanos ${ }^{3}$ — mesmo se boa parte das questões levantadas pela escavação de um sítio arqueológico gravitam em torno da continuidade ou não da habitação daquele sítio por um mesmo grupo étnico ou por uma mesma tradição. ${ }^{4}$ De qualquer forma, concordando em parte com a provocação citada acima, não se pode ou se deve esperar muita coisa da arqueologia para "objetivamente" provar ou ajudar o antropólogo a provar (ou a não provar $)^{5}$ a ocupação tradicional de um sítio ou território por um grupo ou povo.

Apesar dessa constatação, a tese recente de Eduardo Góes Neves (2012) e o artigo de Eduardo Viveiros de Castro (2002) revelaram o grande impacto que a arqueologia amazônica e a ecologia histórica - por exemplo, os trabalhos de Donald Lathrap (1970), Anna Roosevelt (1992, 1993, 1994), Robert Carneiro (1995), Willian Balée (1993) e Michael Heckenberger (1996) — tiveram sobre a etnologia amazônica, em especial a divulgação de dados que evidenciaram, entre outros: estimativas para uma população indígena anterior a 1492 bem maior do que aquelas mencionadas pelo "modelo padrão" de Julian Steward (19461950); complexidade das áreas culturais da floresta tropical mesmo se comparadas à área andina; importância das redes e dos sistemas regionais de intercâmbio nos quais se articulavam sistemas socioculturais em zonas ambientais similares ou distintas (como aquelas das áreas de várzea e terra firme); por fim, a tese segundo a qual a Amazônia seria um centro de “difusão cultural” e não uma área periférica que teria recebido influências do exterior (especialmente dos Andes).

No caso de nossa pesquisa, cujos dados preliminares apresentamos no presente artigo, é evidente que os dados porventura levantados pela arqueologia podem tensionar o modelo atual — construído por autores como Peter Rivière 
(1984) para a região etnográfica das Guianas — , pautado na autonomia e na dispersão dos grupos locais. Como veremos a seguir, se olharmos numa perspectiva de longo prazo ou curto prazo, ou mesmo numa perspectiva sincrônica (mas espacialmente mais ampla), perceberemos no complexo indígena regional do Rio Trombetas ora a sedentarização dos grupos e formação do que poderíamos supor ser um regime próximo ao cacicado, ora a dispersão e frouxidão da organização social, numa dinâmica próxima ao que Pierre Clastres (2003) popularizou como "sociedades contra o Estado". Tudo, mais uma vez, depende da escala espacial e temporal que se escolhe como orientação para a análise, mas também do foco de análise (do olhar) do etnólogo-arqueólogo: o sítio arqueológico de várzea ou de terra firme, ou a articulação entre os dois; a aldeia $\mathrm{x}$ ou a aldeia y, ou a articulação entre as duas (ou mais).

Claro que uma perspectiva articulada entre antropologia e arqueologia (e também história, quando existe documentação) possibilitaria uma melhor compreensão do fenômeno da dispersão e concentração dos grupos indígenas como apostamos no Projeto de Pesquisa Norte-Amazônico. Contudo, somos forçados a admitir, os métodos e as práticas dessas duas disciplinas têm cada vez mais caminhado em direções opostas. Como reconhece Neves (2012), os quatro campos da antropologia boasiana (arqueologia, antropologia cultural, linguística e antropologia física), se no passado não fincaram raízes no campo acadêmico no Brasil, nos últimos anos (a partir notadamente da década de 1970), cederam nitidamente espaço para a etnologia de influência estrutural-funcionalista inglesa e estruturalista francesa. Nessa etnologia, sabe-se, a perspectiva da profundidade temporal é desconsiderada ou deixada em segundo plano em comparação com a perspectiva sincrônica. Mas há diferenças de ordem mais prática entre antropologia e arqueologia que gostaria de colocar em evidência.

A pesquisa participante na antropologia, fundada por Malinowski, permanece um "método de consumo" básico para os antropólogos, ainda que, seja por influência da "aceleração da produção" acadêmica (produzir teses e artigos acadêmicos em maior quantidade e em menor tempo, não importando se rasos), seja por falta de recursos de pesquisa, os etnólogos têm feito cada vez menos pesquisa de campo e ficado menos tempo em campo. Talvez mais importante do que a duração da pesquisa de campo, o que o método malinowskiano nos ensina é a intensidade da relação com os nativos. Participar da vida nativa, falar sua língua, comer sua comida, levar a sério o seu pensamento e, hoje em dia, engajar-se politicamente nas suas demandas, tudo isso parece condições quase essenciais para levar a bom termo uma pesquisa etnográfica. Desse pressuposto metodológico-prático, derivam duas ordens de fato: primeiro, o antropólogo 
no seu trabalho quase sempre se fixa apenas num povo e, na maioria das vezes, numa aldeia, perdendo de vista a dimensão da articulação espacial ou regional entre as aldeias ou do todo de uma área cultural; segundo, o antropólogo quase sempre trabalha individualmente ou, no máximo, em dupla.

De maneira distinta, o arqueólogo, em geral, trabalha em equipe (não necessariamente multidisciplinar) e permanece em estadias muito curtas (em comparação com as do antropólogo) em campo. O objetivo do arqueólogo não é travar relação com o pensamento das pessoas que rodeiam o sítio, ou buscar o ponto de vista delas sobre o mundo revelado pelos elementos materiais e simbólicos dentro e no entorno do sítio. No máximo, os "nativos" são contratados como mão de obra na escavação ou como informantes secundários sobre localização de assentamentos, inscrições rupestres, terras pretas, etc. Tal perspectiva tem sido justificada por aquela pressuposição de descontinuidade entre as populações mais antigas e os habitantes atuais de um mesmo território. Claro que há exceções e gradações nessa perspectiva da arqueologia alheia ao ponto de vista nativo. ${ }^{6}$

Contudo, não acreditamos que esse lugar do pensamento do nativo (mais próximo daquele do antropólogo, mais distante do arqueólogo) seja de fato o ponto mais significativo da separação entre a antropologia e a arqueologia feitas hoje, pelo menos no Brasil. Consideremos dois outros pontos proeminentes da dita separação: o diálogo da arqueologia (e a falta dele, no caso da antropologia) com outras ciências, inclusive aquelas não humanas; a cada vez maior "tecnocientifização" da arqueologia e o flerte da antropologia com experiências descritivas ditas não científicas. Deixemos de considerar os aspectos positivos dos caminhos trilhados tanto pela antropologia quanto pela arqueologia, bem como o fato de que, no percurso desses caminhos, sempre cabem desvios de rotas de acordo com a singularidade de cada pesquisador. Nosso objetivo é apenas apontar, a partir de uma breve consideração, o que faz a arqueologia se distanciar da antropologia nos tempos atuais. ${ }^{7}$

Sabemos todos que a arqueologia, desde há muito tempo, dialoga de forma estreita com outras áreas das ciências humanas, em especial a história, com as ciências da vida e com as geociências. ${ }^{8}$ Lembremos, em primeiro lugar, que em determinados períodos e correntes da antropologia, como no auge do evolucionismo ou no pós-modernismo, a história nunca deixou de ser sua aliada e disciplina auxiliar, porém, noutros períodos e paradigmas — por exemplo, no estrutural-funcionalismo inglês ou no estruturalismo francês - , a história deixou de ser parceira e se tornou uma espécie de incômodo. Ela deveria então ser evitada seja como método, seja como produtora de dados para análise. No Brasil, em especial a partir da década de 1970, o estruturalismo francês encontrou grande 
apelo na etnologia e, assim, a história ficou ainda mais longe do seu horizonte, conforme diz Neves (2012:9). Por outro lado, a história, sobretudo a de longo alcance, nunca deixou de ser fonte de inspiração e disciplina auxiliar da arqueologia na produção e análise de dados. ${ }^{9}$

Além disso, se a arqueologia nunca deixou de contar com o auxílio dos métodos e das técnicas de análise e observação das geociências e das ciências da vida, nos tempos mais recentes, há uma maior sofisticação e especialização no uso das técnicas e dos instrumentos dessas ciências por aquela disciplina. Para corroborar esse ponto, basta consideramos um número especial sobre a metodologia da pesquisa arqueológica, publicado no Boletim do Museu Paraense Emílio Goeldi e organizado por Denise M. C. Gomes (2013). Nos artigos, um conjunto de técnicas mais recentes empregadas pela arqueologia é descrito de tal forma que uma breve olhada permite constatar uma crescente tecnocientificidade da disciplina, em que se tornam indispensáveis técnicas oriundas da computação, da caracterização físico-química dos vestígios, da aplicação da geofísica: flotação, recuperação de macrovestígios vegetais, análise de pólen, fitólitos, extração de microvestígios, análise química dos pisos de ocupação e traceologia lítica; uso conjugado de registros tradicionais, como fotografia e decalques com papel vegetal e lápis, ou com uso de tecido branco e carbono, técnicas de laser scanning terrestre e fotogrametria de luz estruturada; técnicas de fluorescência de raios $\mathrm{X}$, microscopia eletrônica de varredura, espectroscopia por dispersão de energia; uso de radar de penetração no solo (GPR); e utilização do Sistema de Informação Geográfica (SIG), que permite "visualizar por meio de mapas a associação de diferentes variáveis relacionadas à localização, cor do solo, quantidade de artefatos, profundidade e topografia" (Gomes, 2013: 513-516).

Ora, tais técnicas da arqueologia, que demandam o uso de instrumentos de análise sofisticados e caros, contrastam com o "arcaísmo" do caderno de campo do antropólogo (no máximo, acompanhado de um gravador e de uma máquina fotográfica), o uso da observação direta e o domínio da língua. O que quero insistir aqui é sobre o fato de que não é tanto a vocação multidisciplinar da arqueologia (em especial no seu diálogo com as ciências da vida e as geociências) o que mais a afasta da antropologia; isso se dá, em realidade, por seu crescente domínio e uso do aparato técnico-cientificista — o que, de forma coerente, a distancia também do diálogo com o pensamento "nativo" ou daqueles homens que vivem ou viveram num determinado sítio e que são objetos de estudo do arqueólogo.

Isso não é tudo. O arqueólogo tende a se afastar do antropólogo pelo fato de que a maior parte das suas pesquisas hoje em dia tem sido levada a cabo Anuário Antropológico/2013, Brasília, UnB, 2014, v. 39, n. 2: 161-200 
no contexto da "arqueologia de contrato" e diante da necessidade de produzir "dados" e "resultados" num espaço de tempo curto — a tempo de salvar parte dos vestígios arqueológicos dos empreendimentos (de mineração, construção de hidrelétricas, obras de infraestrutura etc.). Não que não exista também uma antropologia de contrato (ou de produção de laudos antropológicos, cada vez mais requisitados pelo poder público, e pela iniciativa privada em menor escala), mas esse tipo de produção, ao contrário da arqueologia, ainda parece minoritário e secundário em relação à pesquisa básica.

Não quero dizer que a "arqueologia de contrato" seja menos científica do que a outra arqueologia ("fora do contrato") ou que os resultados sejam menos confiáveis ou relevantes. Sequer, aqui, chamo atenção para a dimensão ética envolvida nesse tipo de prática científica, tão somente quero enfatizar o fato de que tais pesquisas estão "presas" e "condicionadas" à produção de resultados dentro de um espaço e de um empreendimento alheios e, às vezes, antagônicos àqueles da ciência acadêmica. Por exemplo, boa parte do material coletado em sítios arqueológicos escavados no contexto da "arqueologia de contrato" é retirada e depositada em ambientes diferentes daqueles nos quais se situavam, perdendo com isso uma das condições indispensáveis para a boa perícia arqueológica: o contexto (a interdependência dos diversos materiais do sítio) dado pela estratificação temporal e espacial dos artefatos nas camadas do solo e no seu ambiente natural ou modificado pela ação humana. Além disso, fora desse contexto, esses materiais não são submetidos à apreciação das populações que vivem no seu entorno, ao contrário, são submetidos, em geral, somente a uma análise "fria” das técnicas e das tecnologias da observação científica.

Em síntese, quero dizer aqui que a antropologia e a arqueologia se afastam cada vez mais de um diálogo na medida em que a segunda se torna mais "técnica”, mais dependente de uma tecnologia da análise e da observação e mais longe da interação com pessoas e grupos não acadêmicos (indígenas, ribeirinhos, camponeses, quilombolas, operários etc.). Essa é a medida inversa daquela em que a antropologia procura se fazer e se consolidar como ciência ou, nas palavras de Lévi-Strauss, como uma "ciência social do observado", que procura o ponto de vista do nativo ou de um "sistema de referência fundado na experiência etnográfica, e que seja independente, ao mesmo tempo, do observador e de seu objeto" (apud Goldman, 2003:462). Ou, ainda, como disse Tim Ingold (2008), a antropologia não estuda sociedades ou pessoas, mas estuda com as pessoas. ${ }^{10}$

Dito isso, e retornarei a esse ponto nas considerações finais, não se trata aqui de pensar que há apenas uma legítima antropologia ou arqueologia — há muitas, e em cada uma existem pontos positivos e negativos, contribuições maiores ou 
menores para o conhecimento de uma forma geral —, mas de defender o valor e a necessidade de uma arqueologia que dialogue de forma mais radical com a antropologia e com o pensamento "nativo". 11

\section{Breve etnografia de uma longa história no complexo cultural Tarumã-Parukoto}

Se há uma pesquisa arqueológica bem iniciada na foz dos rios Nhamundá e Trombetas, que deságuam na margem esquerda do Rio Amazonas (próximo às cidades de Nhamundá, Faro e Oriximiná), ${ }^{12}$ mal foram dados os primeiros passos nesse sentido na extensa região compreendida pelo médio e alto curso desses mesmos rios, que nascem próximo à Serra do Acari (na fronteira do Brasil com Suriname e Guiana). Toda essa região (agora delimitada na presente análise), compreendida pelas bacias dos rios Nhamundá e Trombetas, era ocupada por grupos indígenas que, na sua maioria, se inscrevem naquilo que o antropólogo Protásio Frikel (1970) denominou de "complexo cultural Tarumã-Parukoto" (veja localização geográfica nos Mapas 1 e 2).

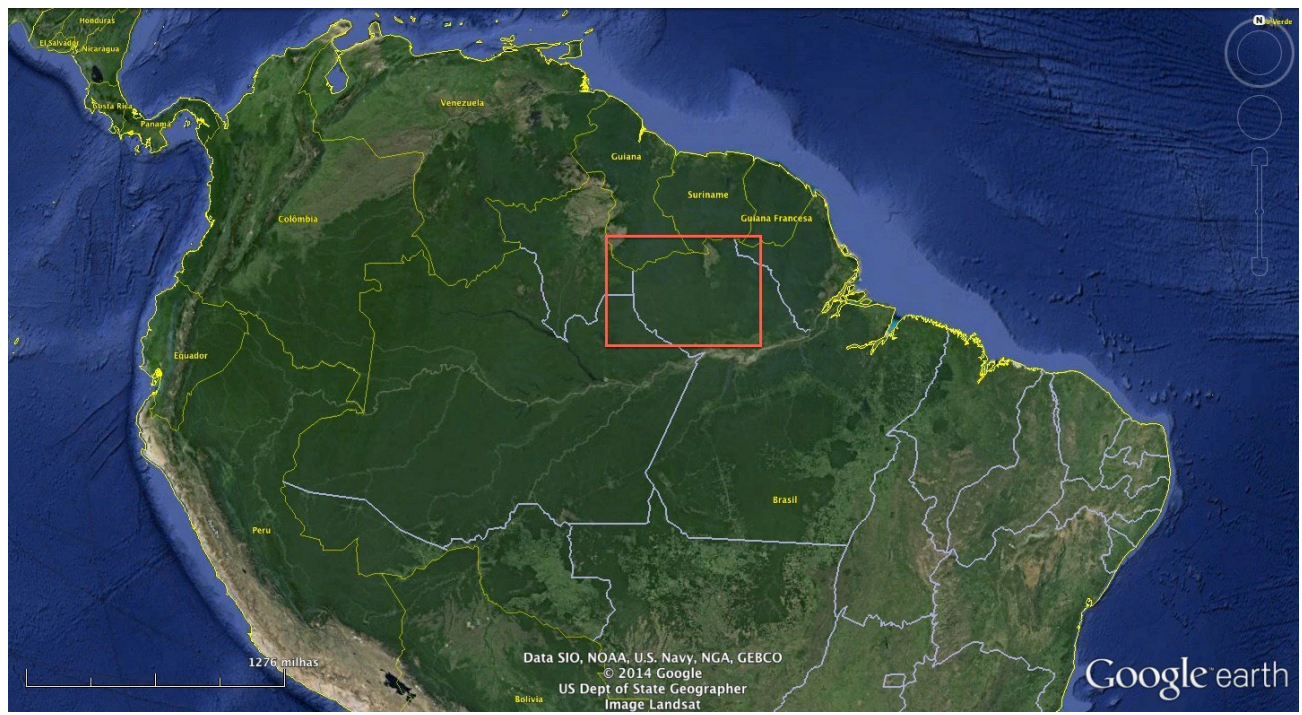

Mapa (1) da Área Etnográfica Tarumã-Parukoto, localizada (no contorno laranja) na Amazônia Setentrional. 


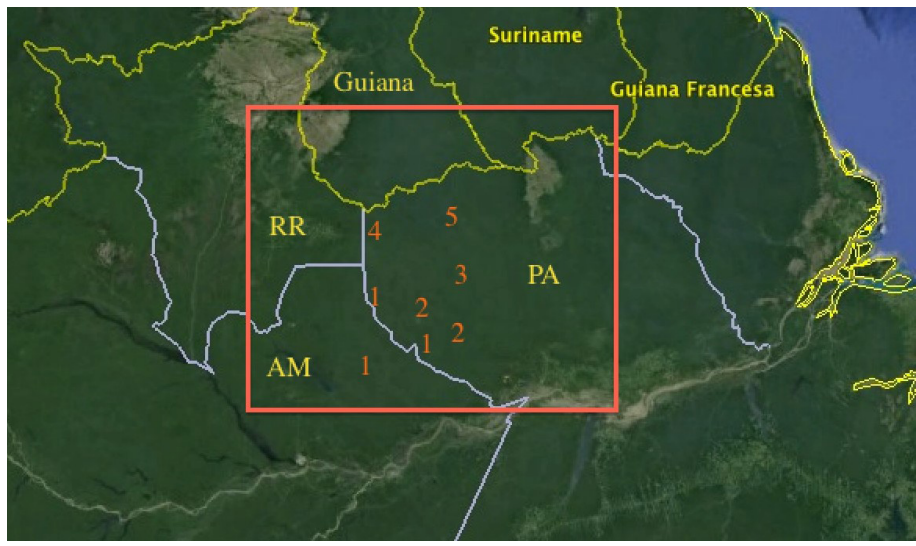

Mapa (2) com distribuição por território dos grupos étnicos na área em estudo.

Os traços essenciais de tais grupos são facilmente delineados a partir daquilo que Peter Rivière (1984) sumarizou para a região das Guianas: aldeias pequenas e impermanentes, regra de residência matrilocal, rituais que envolvem a reunião de várias aldeias e durante os quais são atualizadas narrativas mitológicas, danças, jogos e brincadeiras. Nesse contexto, é difícil falar de um grupo “étnico”, com fronteiras definidas, seja do ponto de vista linguístico, seja do ponto de vista "cultural", pois os inúmeros casamentos entre esses grupos da região promovem necessariamente uma "mistura" ao longo do processo histórico, no qual as pessoas circulam entre as aldeias e adotam vários locais de moradia ao longo do ciclo de vida. Para facilitar a leitura da situação atual, podemos descrever as aldeias de acordo com os principais rios da região e, de certa maneira, esses rios funcionam como marcadores dos lugares aos quais pertence "originalmente" cada um dos subgrupos nesse macroconjunto do "complexo cultural Tarumã-Parukoto".

É possível ver na região um conjunto de grupos que ainda podem ser localizados e discernidos do ponto de vista geográfico e até mesmo linguístico, apesar da fusão em torno de uma unidade genérica denominada "Waiwai" fusão mais ou menos imposta pela ação missionária evangélica a partir de 1950, conforme veremos (Frikel, 1972; Caixeta de Queiroz, 2008; Howard, 2003). Temos, por exemplo, os Mawayana, que são originários do Rio Urucurim e que falam uma língua materna de origem aruaque, em oposição aos demais grupos, que são de língua caribe, mas mantêm uma distinção cultural coerente com a ocupação tradicional de uma área geográfica específica, por exemplo (ver Mapa 2): 1) os Hixkaryana, dos rios Nhamundá e Jatapu; 2) os Xereu-Hixkaryana, do Rio Acari e Médio Rio Mapuera; 3) os Xereu-Katuena, do Alto Rio Cachorro e do Rio Cachorrinho; 4) os Karapawyana e os Waiwai, do alto rio Mapuera e do rio Baracuxi. 


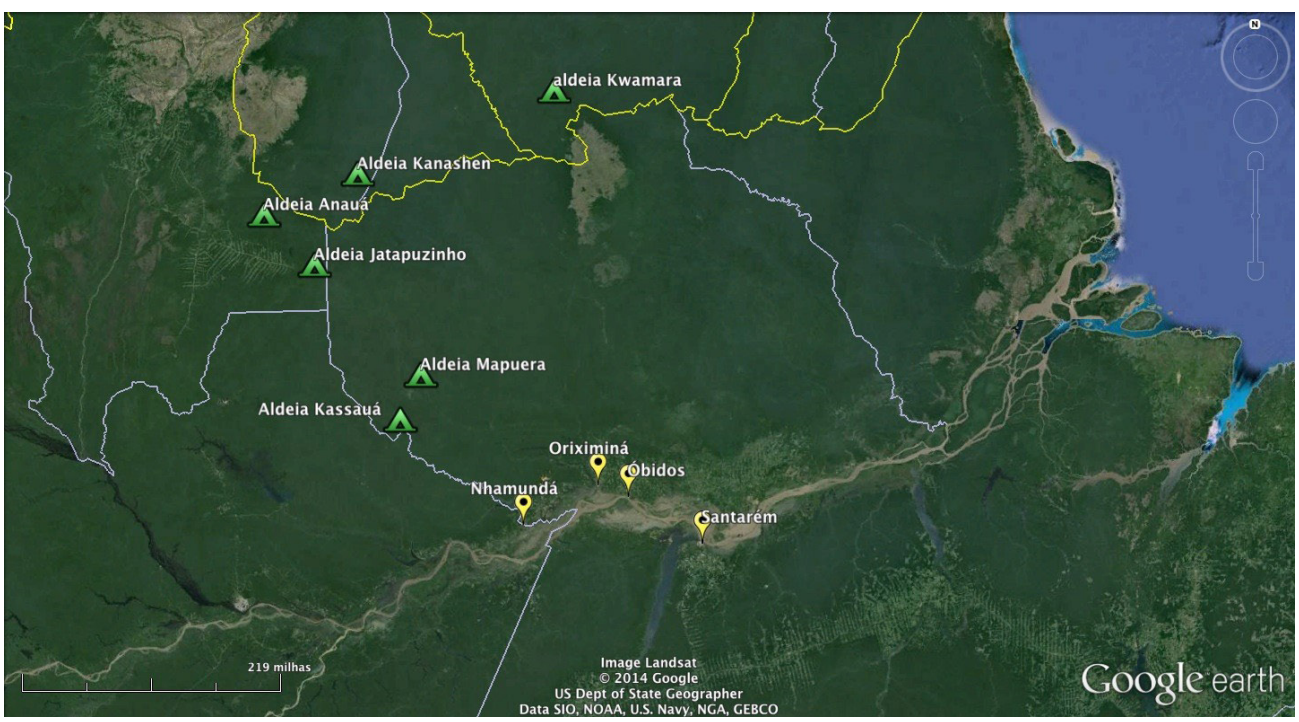

Mapa (3) municípios no baixo curso dos rios Nhamundá e Trombetas e principais aldeias na área estudada hoje.

Sobre os documentos e registros históricos acerca desses grupos indígenas, possuímos poucas informações (tal como há uma ausência de dados arqueológicos) e, menos ainda, sínteses e análises confiáveis sobre os poucos registros existentes. Há referências esparsas sobre os índios Conduri, que teriam sido reunidos, no início da ocupação europeia do continente, na localidade onde se situa a atual cidade de Nhamundá, no Amazonas. Tais índios também teriam sido avistados pelo missionário espanhol Samuel Fritz por volta 1691, no mesmo local onde se iniciaria, seis anos depois, a construção do Forte de Pauxis, nome em referência à denominação do grupo indígena que ocupava a redondeza — local onde hoje está situada a cidade de Óbidos, no Pará (Guapindaia, 2008:17) (ver Mapa 3). ${ }^{13}$ Segundo Frikel (1970:38), o Forte de Pauxis "precisou sempre do braço indígena para sua construção, conservação e manutenção. Muitos dos índios se evadiram devido aos maus tratos que recebiam. Por isso, a população, de vez em quando, foi reforçada por descimentos de silvícolas do Rio Trombetas”.

Talvez o documento mais importante e confiável sobre os indígenas na região etnográfica que estamos aqui analisando, do início da conquista europeia até o final do século XVIII, seja aquele produzido pelo Frei São Manços (1903). Esse documento foi submetido a uma recente e detalhada análise por Porro (2008), que faz, no nosso entendimento, uma leitura geográfica e etno-histórica correta do que foi visto e descrito pelo missionário. Em 1725, sob o comando de Frei Francisco de São Manços, ao que se saiba, o primeiro português a subir o Alto Rio Trombetas, foram realizadas três expedições com o objetivo de localizar e 
atrair indígenas para as missões-aldeias no baixo curso desse rio. Tais expedições foram descritas por Frei Francisco de São Manços no seu "Relatório apresentado ao rei pelo irmão F. De São Manços, religioso da ordem da Piedade e missionário na vila de Nhamundás sobre sua viagem pelo rio Trombetas em 6 de janeiro de 1728". Segundo Porro (2008:387), a importância desse documento deve-se ao fato de que ele nomeia e localiza um conjunto de cerca de 50 "nações" indígenas, "quase todas ignoradas pelas fontes históricas e etnográficas posteriores, além de mencionar muitas de suas aldeias e de seus chefes".

Francisco de São Manços era o frei responsável pela vila de São João Batista de Nhamundás (atual cidade de Nhamundá). ${ }^{14} \mathrm{Na}$ sua primeira viagem ao Rio Trombetas, em 1725, o frei encontrou os índios Abuí (Wabuí) no lago de mesmo nome, na margem direita do rio, de frente ao atual Lago Jacaré (Frikel, 1970:38), que se localiza logo abaixo da atual vila quilombola de Cachoeira Porteira. De lá, disse Porro (2008:388), foram trazidos e assentados "na missão 162 índios da nação Babuhi [Uaboy], além de 70 da nação Nhamundá, provavelmente do rio homônimo".

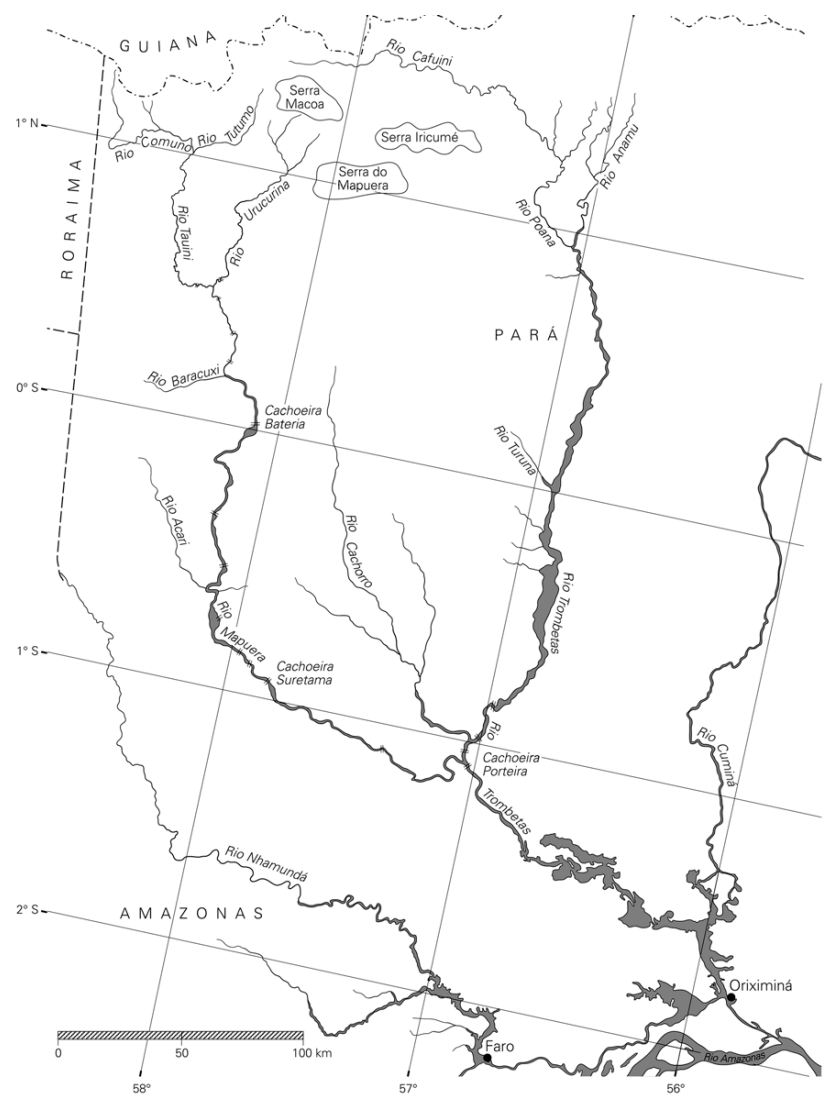

Mapa (4) das bacias do Trombetas e do Mapuera no Noroeste do Pará, a partir de Porro (2008:389).

Anuário Antropológico/2013, Brasília, UnB, 2014, v. 39, n. 2: 161-200 
Uma segunda expedição solicitada por Frei Manços foi realizada em 1726 pelo seu assistente Frei Francisco Alvor, acompanhado de 41 índios, além do soldado Francisco Dias, do presídio de Óbidos. Nesse empreendimento, os expedicionários conseguiram arrebanhar para a missão apenas um casal da "nação" Parukoto habitante do Rio Urucurim. Informado pelo seu assistente de que nas cabeceiras do Rio Trombetas (na verdade, como demonstra Antônio Porro, do Rio Mapuera $)^{15}$ haveria inúmeras "nações” incógnitas, o próprio Frei Manços fez uma terceira expedição, subindo o Rio Trombetas a partir da vila de Nhamundá, no dia 28 de outubro de 1727. De acordo com a síntese de Porro (2008:394),

diversos chefes de aldeias vieram e ouviram sua exortação para que descessem com ele em seu retorno à missão do Nhamundá. Ao final dos entendimentos, o "chefe maioral" daqueles Parukotó, Teumigé, da aldeia de Moxotoreí, determinou que dois outros chefes subalternos seus, Maxacari, da aldeia de Moiri, e Tomari, da aldeia de Momonhari, fossem com o missionário. A 19 de dezembro, a expedição começou a viagem de regresso levando consigo, ao todo, 40 índios parukotó; chegaram sem maiores incidentes à missão do Nhamundá a $1^{\circ}$ de janeiro de 1728.

Dessas expedições e do relatório de São Manços, podemos extrair quatro conclusões importantes para nosso argumento: 1) o Rio Mapuera e seus principais afluentes da margem direita (rios Acari, Baracuxi, e Tauini) e da margem esquerda (Rio Urucurim) eram habitados por uma grande quantidade de grupos ou "nações" distintas, ${ }^{16}$ sendo citadas mais de 50; 2) todos esses grupos ocupavam a bacia do Rio Trombetas, área que se constitui, pois, como unidade territorial e etnográfica ocupada por diferentes grupos indígenas, com dialetos distintos, mas inscritos num mesmo complexo cultural; 3) esses grupos mantinham-se relativamente isolados em relação às frentes de penetração da colonização portuguesa a partir da foz do Rio Trombetas (Frei São Manços teria sido o primeiro missionário português a subir esse rio, conforme citado); 4) contudo, essas "nações" indígenas não estavam sem contato com a colonização europeia; muito pelo contrário, no século XVIII, sofriam pressão do norte, exercida pelos holandeses, que buscavam mão de obra escrava em troca de mercadorias manufaturadas. Para confirmar esse último ponto, podemos citar uma interpretação de Porro (2008:396) sobre o relatório de Manços:

A guerra, sob forma de ataques, incursões e razias, parece ter sido uma modalidade habitual de relações intertribais. Uma das suas principais finalidades, senão a principal, era a obtenção de escravos destinados ao escambo por mercadorias. A nação dos Paranancari [Faranakaru], do extremo norte, era a 
“primeira que recebe 'fazendas' [mercadorias] da mão do Holandês, para as distribuir e passar [trocar] por escravos por todas as nações que ficam pelos rios".

Como já foi citado, o Frei Francisco de São Manços, nas suas expedições de 1726, numerou cerca de 50 "nações", num relato detalhado, que incluía em boa medida os nomes dos rios, das aldeias e dos chefes ou "principais" de cada “nação”. Contudo, o estudo crítico de Antônio Porro (2008:394) considerou: 1) que essas diversas "nações" faziam parte, em geral, de um maior e extenso "grupo"; 2) que as diferentes designações eram na verdade de subtribos ou linhagens. Segundo esse autor (Porro, 2008:394), há uma indicação de que todas essas "nações" correspondiam às "terras e sertões do gentio Parucuató”, termo que, aliás, para um etnólogo moderno, "é quase sempre usado como nome coletivo para as tribos do Mapuera [...]. Todavia, parece que também existe uma tribo autônoma com este nome" (Frikel, 1958:168). Na ausência de qualquer indicação linguística ou de efetivos demográficos, seria razoável supor que as "nações" de São Manços fossem, na verdade, subtribos ou linhagens, se não fossem os dados levantados e as formulações propostas pelos etnólogos a partir da segunda metade da década de 1970. Esses dados e formulações desconstroem o uso de tais termos na descrição das sociedades indígenas das Guianas, em específico, e das terras baixas, de uma forma mais geral.

É preciso fazer duas considerações sobre a observação de Porro. Em primeiro lugar, de acordo com os estudos etnográficos na região, por exemplo, aqueles de Peter Rivière (1969, 1984), não há na área cultural das Guianas — onde se situam essas "nações" do vale do Rio Trombetas — um tipo de organização baseado na subdivisão em tribos ou linhagens. Em segundo lugar, mesmo que houvesse uma designação genérica para os diversos grupos Parukoto, como acredita Protásio Frikel (1958), tudo leva a crer que os pequenos grupos não se viam constituídos numa unidade maior, mas tão só a partir de seus pequenos grupos locais, o que não os impedia, evidentemente, de traçar relações de comércio e guerra com os grupos de "fora".

De qualquer forma, depois do relato detalhado de São Manços, no início do século XVIII, passaram-se mais de 100 anos sem que se tivesse informações mais acuradas sobre os povos do Rio Trombetas. Provavelmente pelo fato de estarem, nesse século, localizados na sua maioria acima das cachoeiras, que dificultavam o acesso, tais povos não sofreram grandes impactos da exploração colonial. ${ }^{17}$ Somente no início do século XIX é que os indígenas ali situados (nos rios Nhamundá e Trombetas) sofreram, talvez, uma ameaça mais direta, ao se 
depararem com a subida dos "mocambeiros" ou dos negros que fugiam da perseguição dos seus senhores e das fazendas situadas na foz desses rios do Amazonas. Essa perseguição foi mais tenaz a partir da Cabanagem.

A Cabanagem foi uma revolta que ocorreu entre 1831 e 1840 na então Província de Grão-Pará, para a qual índios e escravos foram mobilizados. ${ }^{18}$ Segundo Acevedo e Castro (1993:40), "o médio e baixo Amazonas e seus afluentes foram atacados pelos Cabanos, especialmente Óbidos e Alenquer em 1835”. Muitos escravos, diante da morte de seus senhores, aproveitaram para fugir e reorganizaram-se em mocambos (ou quilombos) acima das cachoeiras dos principais afluentes do Rio Trombetas, empurrando os indígenas ainda para cima dessas mesmas cachoeiras. ${ }^{19}$

Somente um tempo depois do final da escravidão, a perseguição aos quilombos arrefeceu, e os negros puderam regressar para as "águas mansas" (abaixo das cachoeiras) do Rio Trombetas, aliviando a pressão dos quilombolas sobre o território ocupado pelos indígenas nas cabeceiras. Contudo, não findou (talvez tenha mesmo aumentado) o processo de conversão ao cristianismo, de pregação dessa fé entre índios e negros, de "descida" dos índios e de formação de "vilas" cristãs. Nesse sentido, é necessário apontar que a atual vila de Oriximiná, do Baixo Rio Trombetas, foi erguida sobre uma antiga aldeia indígena, sob o comando do Padre Nicolino, ele mesmo um índio convertido dos antigos Hixkaryana habitantes do Rio Nhamundá, que tinha como missão catequizar os índios do Rio Trombetas. Com base nas fontes jornalísticas da época e nas informações da Prelazia de Santarém, Funes (2004:11), nos faz a seguinte citação:

Em 28 de setembro de 1890, chegou a Uruá-Tapera, Gonçalves Tocantins, que a descreveu como uma florescente povoação à margem esquerda do Trombetas, que poucos annos antes havia sido fundada pelo Padre Nicolino (dez. 1877) [...]. Alma verdadeiramente christã, se havia feito espontaneamente um missionário, um apostolo daquella pobre gente. Imagine-se com quanto alvoroço aquelles infelizes recebiam o ministro Redemptor, que ia procurá-los nos desertos, baptisar-lhes os filhos, celebrar missa, casamento, e levar-lhes palavras de conforto e consolação. Dois ideais empolgaram a vida do Pe. Nicolino: "A pacificação e cristianização dos pretos mocambeiros dos rios Trombetas e Erepecurú e a catequese entre os índios.” Para alcançar tais fins, empreendeu várias viagens por estes rios. Assim, o vemos em 1876 em Porteira, no alto Trombetas, catequizando e batizando grande número de pretos daquela região. Faleceu em 1882, no rio Erepecurú, quando fazia sua terceira viagem a esse rio. 
Apesar disso, tais expedições missionárias não conseguiam atingir os índios situados mais nas cabeceiras dos rios e é bastante razoável a hipótese de que muitos desses grupos tenham permanecido ali isolados até por volta dos anos de 1950. ${ }^{20}$ Como já dissemos, tal hipótese não quer dizer que, num passado mais distante, tais grupos estivessem sem qualquer tipo de contato com o mundo não indígena ou com outros grupos indígenas da região. Ao contrário, por exemplo, sabemos que, no começo do século XX, os índios Tunayana e Katuena do Rio Turuni (afluente do Alto Rio Trombetas) trocavam bens (cachorros, papagaios, ralos de mandioca) por terçados, machados, miçangas, facas e tesouras de fabricação holandesa, sendo estes provavelmente adquiridos através de trocas com os índios Tiriyó, que, por sua vez, os tinham obtido pelo escambo com os negros marrons da região. ${ }^{21}$

Sem dúvida, o empreendimento missionário de maior impacto para os indígenas na região ocorreu por conta da frente formada por cristãos evangélicos americanos, na sua versão fundamentalista, por meio da Unevangelized Fields Mission (UFM). Tais missionários, que entraram no Brasil pela Guiana na década de 1940, fundaram mais tarde a Missão Evangélica da Amazônia (MEVA) e participaram de inúmeras campanhas e expedições para conversão religiosa de vários povos, entre eles, os Waiwai. Instalados do lado da Guiana e do Suriname, os missionários organizaram verdadeiros "exércitos" e enviaram centenas de expedições ao território brasileiro, com o intuito de deslocar a população indígena do Brasil para aqueles países vizinhos. Muitas dessas expedições foram bem-sucedidas, e os índios foram deslocados de suas terras tradicionais para viver ao lado das missões religiosas no sul da Guiana e do Suriname. Por exemplo, em 1949, os irmãos Rader, Neill e Robert Hawkins subiram o Rio Essequibo (Guiana), com o auxílio de guias indígenas da etnia Wapixana, até um lugar habitado pelos índios Waiwai. Mais tarde, fundaram nas cabeceiras desse rio uma base, denominada Kanashen, e para lá atraíram vários grupos que tinham seu território tradicional de habitação do lado brasileiro, entre eles, os Waiwai (Rio Baracuxi), os Hixkaryana (Rio Nhamundá), os Mawayana (Rio Urucurim), os Tunayana e os Katuena (Rio Turuni ou Turuna), os Kahyana e os Tikiana (Rio Trombetas), e os Xereu (Rio Acari e Baixo Rio Mapuera).

A atração e o movimento de conversão dos índios Xereu, por exemplo, aconteceram em 1954. Os missionários Robert Hawkins e Claude Leavitt (este último tinha se juntado aos irmãos Hawkins em 1953) desceram o Rio Mapuera, acompanhados de índios Waiwai, anunciando o fim iminente do mundo. Os Xereu do Baixo Mapuera, temerosos, mudaram-se para perto da missão na Guiana, onde acreditavam estar mais protegidos. Além do discurso escatológico, os 
missionários prometiam aos índios habitantes do lado do Brasil, se eles mudassem para perto da missão na Guiana, remédios e presentes do tipo armas de fogo, miçangas, facas e espelhos. O missionário Claude Leavitt resumiu o espírito de sua missão:

Provavelmente existem outros duzentos índios do outro lado da fronteira do Brasil, e é neles que estamos realmente interessados. Os Waiwai da Guiana atuam como sementes, propagando a Palavra para eles — por isso é que estamos concentrando nossos esforços para convertê-los antes de tudo. Entrementes estamos tentando convencer os índios brasileiros a abandonar suas aldeias e vir morar aqui. Oferecemos-lhes facas, espelhos, miçangas - tudo o que apreciam. Enviamos mensageiros através das fronteiras, para contar-lhes que aqui viveriam muito melhor (Guppy, 1958:20).

No começo da década de 1960, esse mesmo grupo de missionários expandiu seu campo de ação para o Suriname, criando duas missões: Araraparu, no Rio Kuruni; e Paruma, no Rio Paloemeu. Frikel dizia em 1971:

O procedimento destes missionários entre os Tiriyó do Suriname é simplesmente uma repetição daquele de alguns anos atrás, na região do alto Mapuera. A Missão de Araraparu, por exemplo, foi fundada com um núcleo de algumas famílias Waiwai cristianizadas, trazidas de Kanashen (Guiana) para servir de sementeira da "Palavra". Depois de conseguirem os primeiros adeptos entre os Tiriyó, estes, juntamente com alguns Waiwai, foram mandados para as aldeias Tiriyó, não somente no lado de Suriname, mas especialmente para o lado brasileiro, onde existiam mais aldeias Tiriyó do que no lado norte do Tumucumaque. [...] Na Missão do Paruma (Paloemeu), o procedimento era, basicamente, o mesmo. Naquele rio existiam, até então, duas aldeias Tiriyó e mais duas Wayana. Estes elementos, juntamente com algumas famílias Dyuká, formaram a base para a fundação daquela Missão, e de lá saíram, igualmente, mensageiros da "Palavra" para atrair os indígenas do lado brasileiro (Frikel, 1971:31-32).

Em 1974, devido à chegada ao poder na Guiana de um governo de tendência socialista, avesso à atuação missionária americana naquele país, os índios foram incentivados pelos mesmos missionários a retornar para o lado brasileiro. Dessa forma, foram constituídas duas novas aldeias-base do lado brasileiro: uma denominada aldeia Kaximi, no Alto Rio Novo, afluente do Rio Anauá, onde hoje se localiza a Terra Indígena Waiwai; a outra denominada aldeia Mapuera, localizada no rio homônimo, afluente do Rio Trombetas. Essa última aldeia foi localizada num lugar de tradicional habitação dos índios Xereu, que tinham também 
migrado para a Guiana. Para fundar a aldeia no Rio Mapuera, os índios vindos da Guiana contaram com o apoio de parte dos índios Hixkaryana do Rio Nhamundá (aqueles que não haviam migrado para a Guiana, permanecendo naquele rio), que disponibilizaram aos recém-chegados de volta mudas de mandioca, banana e cará, entre outras plantas. ${ }^{22}$

$\mathrm{Na}$ verdade, parte dos índios do sul da Guiana, habitantes do entorno da aldeia-missão Kanashen, ali permaneceram. Dessa forma, nas décadas de 19701980 podíamos contar com, pelo menos, seis grandes aldeias pertencentes aos índios do complexo cultural Tarumã-Parukoto: Kanashen (sul da Guiana); Kwamará (sul do Suriname); Anauá (afluente do Rio Branco, estado de Roraima); Jatapuzinho (no rio homônimo, estado de Roraima); Mapuera (no Rio Mapuera, estado do Pará); e Kassauá (Rio Nhamundá, estado do Amazonas) (ver mapa 3).

Até o início da década de 1990, houve um crescimento populacional muito grande na aldeia de Mapuera, chegando a contar com mais de mil habitantes. Isso levou rapidamente ao esgotamento, no seu entorno, de caça, pesca e coleta, assim como diminuiu a disponibilidade de terra fértil para a abertura de roças. Cada vez mais, as famílias tiveram que andar e abrir clareiras de roças em áreas distantes da aldeia, seja rio acima, seja rio abaixo, seja em direção ao interior da floresta. Contudo, se tal dispersão deveu-se à escassez de recursos no entorno da aldeia, outros fatores a alimentaram, como o desejo de reagrupamento de acordo com as unidades territoriais e étnicas anteriores ao contato. Se mantivéssemos um foco aberto sobre essa aldeia Mapuera, digamos, numa visão do alto (como no Mapa 5, concebido a partir da imagem de satélite via Google Earth), observaríamos um aglomerado de casas espalhadas e desordenadas no espaço. $\mathrm{Na}$ verdade, se aproximarmos esse foco, veremos que as casas estão organizadas, na sua maioria, de acordo com o grupo étnico (ou subgrupo) ao qual pertenciam os indígenas antes de a ação missionária os ter levado a habitar um mesmo espaço na Guiana. Ou seja, esses diversos grupos conservaram uma divisão espacial numa mesma aldeia que correspondia às diferentes "identidades" e aos diferentes territórios no passado (antes da ação missionária na década de 1960). Dessa maneira, na imagem abaixo, podemos ver um "bairro" na parte superior da aldeia, no qual se aglomeraram os índios Katuena. Tais índios, antes da ação missionária e até a década de 1960, habitavam fundamentalmente as cabeceiras do Rio Turuni — um afluente da margem direita do Rio Trombetas — e tinham pouco ou quase nenhum contato com os outros grupos do Rio Mapuera (fundamentalmente, os Xereu e os Waiwai).

$\mathrm{Na}$ verdade, alguns subgrupos (como os Katuena), embora compartilhando um espaço contínuo ou próximo de outros subgrupos dentro da aldeia 
Mapuera, sempre possuíram roças separadas, relativamente distantes da aldeia, que funcionavam como uma espécie de "aldeia temporária”. Ali, mantinham uma relativa independência, passavam boa parte da vida cotidiana e elegiam seus locais de caça e coleta. Dessa forma, tais subgrupos puderam desfrutar de uma espécie de "autonomia" do grupo local, sem se submeter aos caciques gerais da aldeia Mapuera, ao seu ritmo coletivo e supraétnico, no qual a identidade maior, denominada Waiwai, mantinha-se como inibidora das diferenças e das "identidades” específicas dos subgrupos. Ou seja, a aldeia Mapuera, nesse caso, funcionou (e ainda funciona) como aldeia central (e as roças, como aldeias satélites), lugar de convergência para as atividades coletivas — em geral, de conteúdo ritual ou político —-, onde os cultos evangélicos têm um papel preponderante.

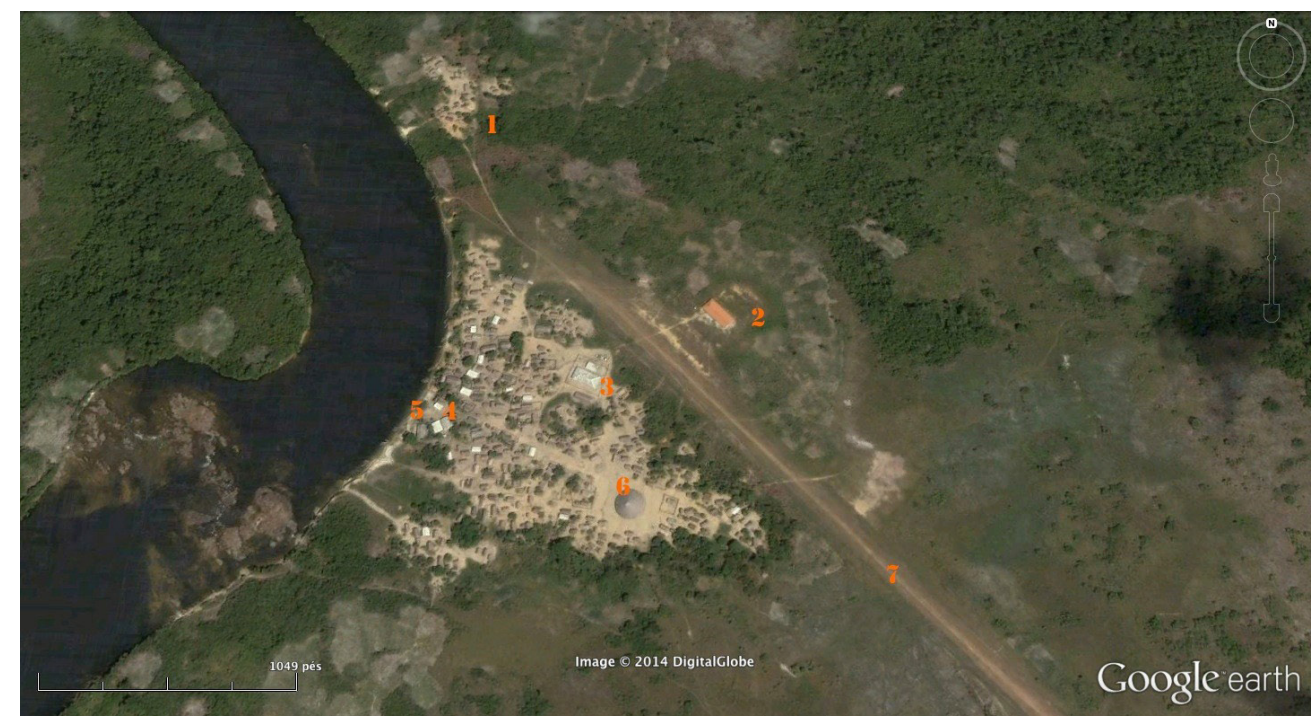

Mapa (5) da aldeia Mapuera: 1) “Bairro” Katuena; 2) Escola; 3) “Igreja”; 4) Posto de Saúde; 5) Posto da Funai; 6) Casa Grande (Umaná); 7) Pista de Pouso.

No final da década de 1990, aprofundou-se o movimento de dispersão e de fuga a partir da aldeia central de Mapuera, com a fundação não apenas de novas roças, mas de novas aldeias:

1) aldeia Tamiuru, na margem esquerda do Rio Mapuera, uma aldeia do povo Katuena, habitante tradicional do Rio Turuni, afluente da margem direita do Rio Trombetas, que tinha sido levado pelos missionários para o sul da Guiana na década de 1960 (e que não se "sentia bem”, nas palavras de seu principal líder, vivendo no meio de "outros grupos);

2) aldeia Pomkuru, na margem direita do Rio Mapuera, acima de Tamiuru, habitada pelo povo Waiwai, que, antes da ida para o sul da Guiana na década de 1950, ocupava a bacia do Rio Barucuxi; 
3) aldeia Uakri ou Bateria, Rio Mapuera acima (depois de Pomkuru), na margem esquerda, habitada pelo povo Parukoto, que também tinha sido levado para o sul da Guiana na década de 1960;

4) aldeia Placa, criada no limite extremo sul da TI Nhamundá/Mapuera, do povo Tunayana, habitante tradicional do Rio Turuni (afluente da margem direita do Alto Rio Trombetas), que tinha sido levado pelos missionários para o sul do Suriname na década de 1960;

5) aldeia Tawaná, criada no final da década de 1990, quase na desembocadura do Rio Mapuera no Rio Trombetas, bem perto da vila de Cachoeira Porteira; ${ }^{23}$

6) aldeia Inajá, na margem esquerda do Rio Mapuera (abaixo da aldeia Placa), fundada por um grande líder do povo Waiwai, Porosha, e composta basicamente por índios Hixkaryana e Xereu;

7) aldeia Kwanamari, na margem esquerda do Rio Mapuera (abaixo da aldeia Inajá), formada basicamente por gente da etnia Hixkaryana-Xereu;

8) aldeia Takará (acima da aldeia Kwanamari), instalada na margem direita do Rio Mapuera, inicialmente formada por índios Yaipuyana, que, mais tarde, absorveu a quase totalidade dos índios Xereu que habitavam a aldeia Inajá;

9) aldeia Mapium, localizada na margem esquerda do Rio Mapuera (abaixo da aldeia Kwanamari), composta por índios dos grupos Mawayana e Tunayana;

10) aldeia Paraíso, criada a partir de uma divisão da aldeia Tamiuru, que se instalou na margem direita do Rio Mapuera, acima da aldeia Takará.

Um movimento de dispersão semelhante aconteceu a partir do mesmo período (final dos anos de 1990) no Rio Nhamundá, entre os índios Hixkaryana, e a partir da aldeia Kassauá. Da mesma forma, já no início do século XXI, podemos ver a reocupação do Rio Cachorro pelos índios Kaxuyana (que tinham sido deslocados para a Missão Tiriyó e para o Rio Nhamundá em 1968 pelos missionários católicos e evangélicos) e a reocupação do Rio Turuni e do Alto Rio Trombetas pelos índios Tunayana e Katuena, que tinham sido deslocados para a aldeia Kwamará (no sul do Suriname) na década de 1960. É importante ressaltar que a maior parte dessas "novas" aldeias nos rios Nhamundá, Cachorro, Mapuera e Trombetas foi criada no mesmo sítio ocupado por antigas aldeias, quase todas em áreas de terra preta, lugares que permanecem na memória dos mais antigos como "aldeias" onde viviam seus parentes no passado mais distante ou próximo.

No mapa a seguir, podemos ver as principais aldeias dispersas na região de fronteira do Brasil e da Guiana no momento atual.

A) No Alto Rio Essequibo (Guiana)

1) Aaku

B) No rio Anauá (Roraima) 
2) Anauá

3) Xaari

C) Nos rios Jatapu e Jatapuzinho (Roraima)

4) Cobra

5) Soma

6) Makará

7) Jatapuzinho

8) Katuau

D) No Rio Jatapu (Amazonas)

9) Bacaba

10) Santa Maria

E) No Rio Nhamundá (Amazonas e Pará)

11) Kassauá

12) Porteira

13) Jutai

14) Riozinho

15) Cafezal

16) Matrinchã

17) Gavião

18) Torre

19) Cupiúba

20) Areia

21) Belontra

F) No Rio Mapuera (Pará)

22) Mapuera

23) Tamiuru

24) Pomkuru

25) Uakri (Bateria)

26) Placa

27) Paraíso

28) Takará

29) Inajá

30) Kwanamari

31) Mapium

32) Yawará

33) Tawaná

G) No Rio Cachorro

34) Chapéu 
35) Santidade

H) No Alto Rio Trombetas

36) Kaspakuro

37) Turuni

38) Ayaramã

I) No Alto Rio Sipawilini (Suriname)

39) Kwamará.

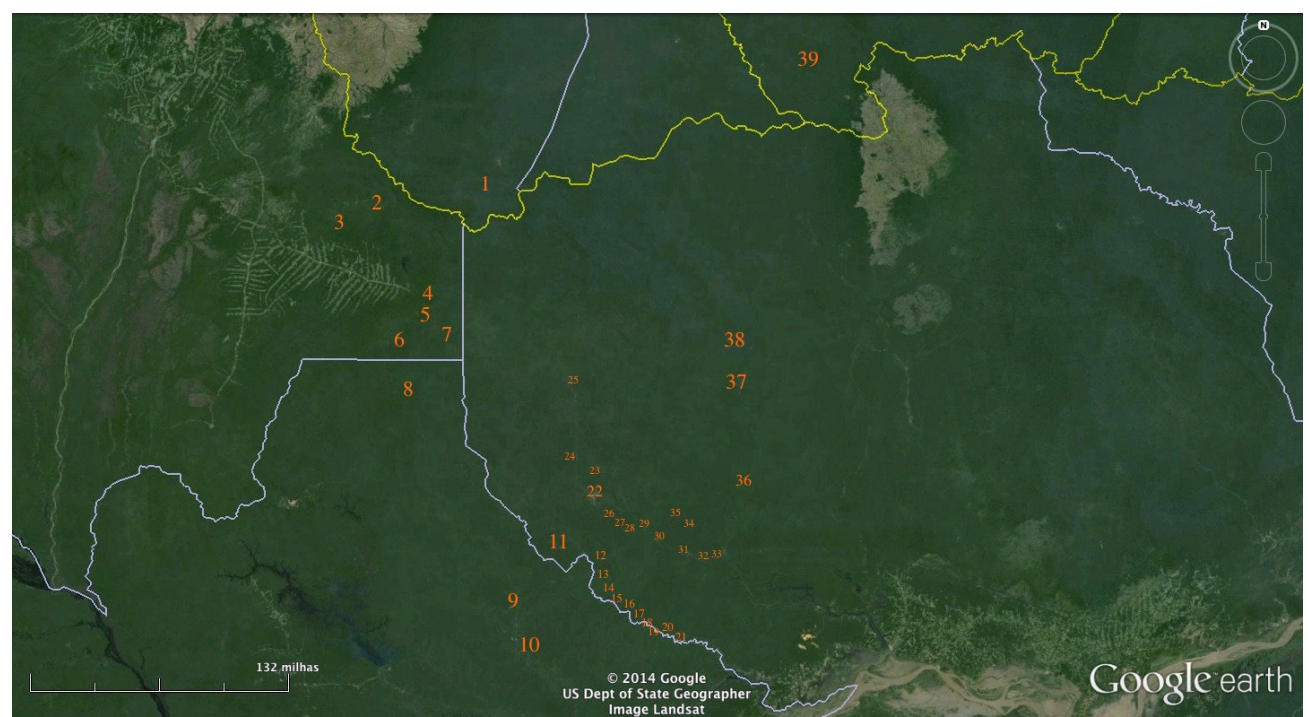

Mapa (6): Distribuição atual das principais aldeias do Complexo Cultural Tarumã-Parukoto na área em estudo.

\section{De volta à arqueologia do Rio Trombetas: o que ela nos informa sobre os dados etnográficos atuais?}

Antes de passarmos às considerações finais, a partir desta breve apresentação do contexto histórico e etnográfico da bacia do Rio Trombetas, voltemos aos dados produzidos pela pesquisa arqueológica para a mesma região. De imediato, como dissemos no início deste artigo, dispomos apenas de dados mais consistentes para o baixo curso dos rios Nhamundá e Trombetas. Sobre essa área, as pesquisas atuais conduzidas por Vera Guapindaia (2008) e por Guapindaia e Aires da Fonseca (2013) têm produzido novas informações, entre as quais cabe destacar: uma maior e mais antiga ocupação humana nas zonas de interflúvio; e um recuo de pelo menos 1.000 anos para a ocupação humana na região em relação ao proposto por Hilbert e Hilbert (1980), que foi, segundo Neves (2012:145), situada entre 1300 e 1000 a.C. 
As pesquisas anteriores na região, conduzidas por Hilbert e Hilbert (1980), davam como certa a ocupação do tipo Pocó apenas na área ribeirinha (restrita às margens dos grandes rios e lagos), que teria ocorrido entre os séculos II a.C e IV d.C., enquanto a ocupação do tipo Konduri teria ocorrido tanto nas áreas ribeirinhas quanto nas áreas de interflúvio entre os séculos X e XV. Diante disso, construiu-se um modelo de ocupação Konduri segundo o qual as áreas de moradia seriam hegemônicas no ambiente ribeirinho, sendo a ocupação dos interflúvios "[...] composta, em grande parte, por acampamentos periódicos e por algumas pequenas aldeias” (Guapindaia e Aires da Fonseca, 2013:659).

Os dados mais recentes apresentados por Guapindaia e Aires da Fonseca (2013) referem-se ao Sítio Arqueológico PA-0R-127: Cipoal do Araticum, situado no município de Oriximiná, numa zona de interflúvio, na área de interferência da mineração de bauxita do Rio Trombetas. Tais dados modificaram aquele panorama traçado pelo trabalho de Hilbert e Hilbert (1980), pois apresentaram para a área de terra firme "atributos conferidos, até aquele momento, aos sítios ribeirinhos: profundas e extensas áreas de terra preta e grande quantidade de material". Além disso, os dados coletados na zona de interflúvio deviam ser correlacionados tanto à ocupação Pocó quanto à Konduri. O sítio Cipoal do Araticum teria sido inicialmente ocupado por volta de 2000 a.C. Segundo Guapindaia e Aires da Fonseca (2013:672),

entre essa data até aproximadamente o ano 1000 A. D., pode-se inferir que a área foi ocupada permanentemente ou que houve vários processos de reocupação. A partir dessa data até aproximadamente o ano 1400 A. D., houve a diminuição das áreas ocupadas, culminando com o abandono. Evidentemente, essa periodização precisará ser relacionada com as duas ocupações ceramistas identificadas no sítio: Pocó e Konduri.

O que esses dados recentes levantados pelos arqueólogos podem nos dizer acerca dos dados históricos e etnográficos sobre o complexo cultural Tarumã-Parukoto apresentados na seção anterior deste artigo? Pouca coisa, ou quase nada. Claro, não podemos garantir nenhuma continuidade entre aquelas ocupações pré-históricas (Kondori e Pocó) e os grupos indígenas do período colonial e, muito menos, os atuais grupos indígenas. Além disso, os grupos indígenas contemporâneos descritos pela nossa breve etnografia estão situados numa região bem mais a montante - isto é, estão nas cabeceiras dos rios — do que os sítios escavados e analisados por Guapindaia e Aires da Fonseca. ${ }^{24}$

Por um lado, a maioria desses grupos indígenas, quando contatados por missionários evangélicos nas décadas de 1950-1960, possuía uma cultura material 
bastante simples: sim, eram ceramistas e consorciavam as práticas de caça e coleta com a agricultura, mas usavam machados de pedra e praticamente não possuíam objetos tais como facão, machado de ferro e miçangas. Por outro lado, como vimos na primeira parte deste artigo, pelo menos do século XVII até o início do século XIX, tais grupos sofreram pressão das frentes de colonização vindas da foz dos rios Nhamundá e Trombetas — inclusive, foram atingidos pela fuga dos escravos no século XIX, que, ao instalarem quilombos rio acima, expulsaram os indígenas ainda mais para as cabeceiras ou para o interior da floresta; da mesma forma, no período colonial, os grupos indígenas dessa região foram atingidos por holandeses que vinham buscar prisioneiros para mão de obra escrava. Então, pelo menos parte daqueles grupos situados mais a montante, após as cachoeiras do Nhamundá e do Trombetas, pode ter sido formada pela junção entre aqueles que já viviam ali e aqueles que subiram a partir da jusante - fugindo das frentes da colonização.

De qualquer forma, as narrativas indígenas contemporâneas informam que, no passado mais antigo, seus parentes viviam mais a jusante e mais próximo da área onde hoje se encontram os sítios Konduri e Pocó - alguns dizem que cidades tais como Oriximiná, Faro e Óbidos foram, de fato, aldeias dos seus parentes mais antigos. Tais narrativas aproximam-se daqueles registros históricos do período colonial que apontam para a existência de períodos de "descimentos" mesclados com períodos de "subimentos" de indígenas em razão da ação missionária ou da pressão das frentes de colonização. Além disso, por um lado, cabe observar que a maioria das aldeias hoje localizadas na região está, de fato, nas margens dos principais rios da região (Nhamundá, Mapuera, Cachorro e Trombetas), o que leva a crer que tais grupos ocuparam um ambiente mais próximo da região de várzea e mais dependente dos recursos dos rios (entre os quais, peixes e quelônios) do que da terra firme. Por outro lado, num passado não distante, antes da década de 1950 (antes do contato promovido pelas frentes missionárias), tais grupos viviam mais no interior da floresta. Ainda hoje, são vários os casos em que os índios nos indicam que as aldeias de seus antepassados estavam localizadas não só nas cabeceiras e nos igarapés, mas, quando perto dos grandes rios, relativamente afastadas das suas margens - entre a aldeia e o rio havia uma faixa de floresta de forma a evitar que, a partir do rio, os indígenas fossem avistados por forasteiros. Claro, tal escolha de localização das aldeias visava camuflar a presença indígena daqueles exploradores e colonizadores que subiam a partir dos rios. Ao mesmo tempo, os grupos indígenas contatados a partir da década de 1950 do complexo cultural Tarumã-Parukoto não eram grandes 
navegadores, já que possuíam apenas pequenas canoas de casca de árvore, que só possibilitavam navegar em pequenos e mansos cursos d'água..$^{25}$

De toda forma, não podemos comparar os dados levantados pela pesquisa arqueológica na região com os da pesquisa etnográfica, seja porque os territórios em que se encontram as populações indígenas atuais e as populações préhistóricas não são necessariamente os mesmos (os primeiros situam-se mais a montante, os segundos situavam-se mais a jusante); seja porque há um longo espaço de tempo entre uns e outros (500 anos são suficientes para que os grupos indígenas se transformem devido a uma lógica interna ou às pressões decorrentes da colonização europeia); seja porque houve ocupações e reocupações de territórios ou sítios sem que possamos saber ou precisar se isso ocorreu por um mesmo grupo étnico ou linguístico ou sucessivamente por grupos diferentes; seja, enfim, porque os grupos humanos adotaram, ao longo do período histórico (e talvez pré-histórico), um movimento de perambulação e migração por razões ambientais - por exemplo, escassez de recursos -, ou em decorrência do contato com os europeus, ou, ainda, devido a fatores internos, como conflitos e guerras.

Seguramente, as pesquisas arqueológicas na Amazônia, e na região do Rio Trombetas de uma forma particular (tais como aquelas conduzidas por Vera Guapindaia), têm revelado uma população indígena anterior à conquista europeia bem maior do que aquela observada logo após tal conquista. Mais do que isso, elas têm demonstrado a improcedência de um argumento que leva a pensar que os grupos ribeirinhos (ou de várzea) eram bem maiores do ponto de vista demográfico, mais sedentários, mais complexos e mais hierarquizados do que aqueles da terra firme. Na verdade, as pesquisas de Guapindaia (2008, 2013) têm evidenciado que, de fato, tais sociedades pré-históricas da área de abrangência do Baixo Nhamundá-Trombetas eram mais numerosas e antigas do que se imaginava há bem pouco tempo (o que vem, na verdade, sendo demonstrado por outros arqueólogos para outras regiões da Amazônia), ${ }^{26}$ que havia uma comunicação bem maior entre os grupos localizados na área ribeirinha e aqueles localizados na terra firme, ou, mais relevante ainda, que um grupo localizado ("sedentário") na área ribeirinha explorava e ocupava temporariamente as áreas de interflúvio, e vice-versa.

Tal observação, validada pelas pesquisas arqueológicas na região a jusante dos rios Nhamundá-Trombetas, acreditamos, está muito próxima daquilo que foi observado para o padrão de assentamento dos atuais grupos indígenas do complexo Tarumã-Parukoto, situados mais a montante desses mesmos rios. ${ }^{27}$ Tais dados, sem dúvida, refutam o postulado básico de B. Meegers (1971), inclusive a partir de suas pesquisas na região ocupada pelos Waiwai das Guianas, 
segundo o qual havia uma frontal oposição entre as áreas de ocupação humana das várzeas - ambiente mais rico em proteínas e mais fértil para a agricultura, o que permitira uma maior concentração demográfica, aliada a hierarquia e sedentarismo - e as áreas de terra firme, ambiente mais pobre em proteínas e menos fértil para a agricultura, o que impedia maior concentração demográfica e acarretava nomadismo e dispersão dos grupos locais. ${ }^{28}$

\section{Considerações finais}

Os dados etnográficos e históricos levantados sobre os grupos do complexo cultural Tarumã-Parukoto que ocupam as bacias dos rios Nhamundá e Trombetas permitem, de fato, afirmar que eles sofreram abalos demográficos e no seu sistema de organização social em razão da conquista europeia. Por um lado, podemos dizer que os grupos encontrados por missionários na década de 1950 dispersos nas cabeceiras dos rios, possuidores de uma cultura material bastante simples, sem hierarquias ou organização política centralizada - já eram formações decorrentes do contato com as frentes de colonização. Tais dados nos levam a concordar com a crítica feita por Anna Roosevelt (1993) ao que ela denominou de "projeção etnográfica": a ideia de que não podemos projetar o estado contemporâneo dos grupos indígenas (que, em função da guerra por captura de escravos e epidemias promovidas pela chegada dos europeus, entre outros agentes e agências externas, teriam sido dispersos, fragmentados, diminuídos demograficamente, empobrecidos materialmente, simplificados socialmente etc.) para aquela situação dos grupos indígenas anteriores à Conquista. Antes, eles seriam mais numerosos do ponto de vista demográfico e mais complexos do ponto de vista da organização social e política.

Por outro lado, se virmos o que foi descrito sobre esses povos no começo do século XVIII por Frei São Manços - numa época em que tais grupos ainda mantinham certa autonomia nas cabeceiras dos rios perante as frentes de colonização -, perceberemos um tipo de organização que se assemelha à dos atuais grupos indígenas dessa região (combinação de autonomia dos grupos locais com lideranças do tipo cacique para um grupo de aldeias). Isso significa que houve, na ordem sincrônica ou diacrônica, a combinação de períodos de concentração e dispersão dos grupos indígenas na região.

Na interpretação de Ana Roosevelt (1992, 1993), houve uma grande ruptura no padrão de organização social e assentamento dos grupos indígenas após a conquista europeia. De fato, se não há como negar tal "impacto destruidor e desagregador” da Conquista, tampouco se pode negar que as populações indígenas souberam, em muitas situações, driblar e exercer o protagonismo nessas 
transformações; e ainda que sempre houve relações de continuidade dentro daquelas rupturas. De acordo com Viveiros de Castro (2002:340-344),

[...] a consequente maior vitimização das populações indígenas pode caucionar uma visão degeneracionista dos grupos sociais, que lhe nega qualquer capacidade de autodeterminação histórica e, no limite, pode desembocar na absurda conclusão (que nenhum de nós subscreveria, mas aos índios não faltam inimigos poderosos) de que as sociedades contemporâneas, sendo não-representativas da plenitude original, são descartáveis, isto é, podem ser assimiladas à sociedade nacional sem maiores perdas para a humanidade. Se a projeção etnográfica tem certamente seus perigos, não se pode desprezar o risco inverso, o de uma "perversão arqueológica", sobretudo em um momento em que os povos nativos vêm utilizando sua ligação histórica com o passado para justificar sua presença na cena política mundial, e assim assegurar o seu futuro.

Voltaremos a esse ponto para a conclusão do artigo. Por ora, cabe destacar que os diferentes arranjos sociopolíticos e tipos de assentamentos (sedentários ou temporários) obedecem tanto a fatores exógenos (disponibilidade e escassez de recursos; conflito e alianças com o mundo não indígena) quanto a fatores internos (sociologia e cosmologia) a cada grupo ou complexo cultural. Neste artigo, procuramos apresentar, por meio de um caso etnográfico (do complexo cultural Tarumã-Parukoto), como ocorre a concentração e a dispersão dos grupos indígenas numa perspectiva diacrônica e ao mesmo tempo sincrônica. Partimos do pressuposto de que esse movimento de dispersão e fusão ocorre na linha do tempo, porém, por se tratar de uma realidade persistente, pode ser verificável na ordem sincrônica da vida local. Neste último caso, queremos dizer que esse movimento de fusão-dispersão é constitutivo do socius e da cosmologia ameríndia, o que equivale a dizer, de outra maneira, que o movimento de descentralização e de concentração nunca se conclui totalmente - ao pender para um lado, há, simultaneamente, uma força puxando no sentido contrário. De forma explícita, estamos aceitando a figura do pêndulo construída pelos trabalhos de Sztutman (2009, 2012a, 2012b) e Perrone-Moisés \& Sztutman (2010). O próprio Sztutman (2012b:210) explica, sobre a utilização da imagem do pêndulo:

Beatriz Perrone-Moisés, debruçada sobre relatos acerca de confederações entre os povos caribe da região das Guianas e em outras partes da América, conceitualizou esse movimento oscilante — de certo modo, pendular — como um “dualismo em perpétuo desequilíbrio”, propriedade que Lévi-Strauss reconhece como motor de todo pensamento ameríndio. Em um ensaio escrito em conjunto, desenvolvemos a ideia de que esse movimento pendular deveria 
ser pensado como um elemento estrutural de longa duração, sendo portanto capaz de conferir alguma continuidade entre os eventos do passado - apreendidos pelos arqueólogos e historiadores - e os eventos do presente - apreendidos pela etnografia. Tentamos manter o sentido mais dinâmico do termo "estrutura", como algo mais próximo de uma matriz intelectual para a criação de novas formas sociopolíticas. Essa alternância ocorreria, via de regra, entre um pólo dispersivo e um pólo centralizador, evitando toda tendência de fixação em um deles, isto é, mantendo-se contrária tanto à configuração de uma interioridade enrijecida como o Estado quanto a uma situação de pulverização total, significando a abolição da toda vida social.

Passado o efeito mais drástico da desterritorialização e do contato e da colonização, aqueles grupos indígenas isolados (e "deslocalizados") do complexo cultural Tarumã-Parukoto, a partir da segunda metade do século XX, começaram a refazer sua rede de alianças internas com outros grupos indígenas - mantendo e alargando essa mesma relação com o mundo dos brancos - , ao mesmo tempo em que se iniciou um processo de reterritorialização, de "indigenização" ou de "ressurgimento étnico". Como disseram Fausto e Heckenberger (2007), nesse processo de desterritorialização e de reterritorialização, devemos levar em conta duas ordens de fatores: 1) o processo de contato entre índios e brancos não seguiu apenas numa direção, isto é, do pouco ao intenso e, às vezes, permanente contato, mas constituiu-se num processo de intensificação e distanciamento, num "movimento de maré"; 2) nos dias de hoje, constata-se, portanto, um movimento em direção à promoção da "identidade étnica" ao mesmo tempo que ocorre o "alargamento" da rede de aliança entre índios e entre índios e brancos (por meio dos programas de assistência do Estado e de organizações não governamentais, por exemplo). Vejamos o que dizem os autores:

Discontinuity was a crucial feature of the colonial process in Amazonia. Moments of expansion were intermingled with periods of retraction in such a way that interethnic relations were based on cycles of contract and isolation. These reflected to some degree the rhythm of the extractivist economy, which was highly sensitive to world system trends [...]. This tidal movement had two basic consequences. First, it generated new "discoveries". The nineteenth-century rubber economy drew back into the system peoples who had been subjected to missionary influences more than a century before. Twentieth-century state agents contacted "pristine" peoples already attacked by seventeenth and eighteenth-century bandeirantes. Native groups also enacted the "discovery" of whites and commodities more than once [...]. The second consequence was 
that these cycles of contact and isolation created a special dynamic for social and cultural phenomena. Periods of retraction were particularly rich in terms of the reorganization and re-creation of native societies, prompting historical processes whose rationale was only partially — or even marginally — colonial. This fact is commonly obscured by ethnohistory, whose focus tends to be either on processes of regression under external pressure or on the interaction between whites and natives, as though indigenous history becomes history only when we enter the equation [...] (Fausto \& Heckenberger, 2007:17).

Na exposição do caso etnográfico Tarumã-Parukoto, para compreender o movimento de dispersão e concentração dos grupos indígenas que ali habitam, recorremos ao uso da pouca história disponível, assim como de uma perspectiva regional. Isto é, não foi suficiente manter o foco apenas numa aldeia (como, de fato, procede boa parte das etnografias sobre a região), nem apenas no presente. Ainda que de forma sintética e esquemática, apresentamos dados de uma longa história (no mínimo três séculos), numa dimensão espacial ampla (na situação atual, 39 aldeias espalhadas no sul do Suriname e da Guiana, no oeste do estado do Pará e no leste dos estados de Roraima e Amazonas). Claro que perdemos com esse largo escopo histórico e espacial a dimensão particular do dado etnográfico, mas ganhamos ao mostrar as relações regionais entre os grupos indígenas (que nunca estão isolados) e o seu dinamismo transformacional (que inclui situações de continuidade e rupturas com um determinado padrão) no contato entre os grupos indígenas e deles com a sociedade envolvente.

Nessa perspectiva de larga escala, perguntamo-nos se poderíamos passar de um conjunto de informações propriamente etnográfico-históricas para aquele que foi fornecido pela pesquisa arqueológica na região. Concluímos, em sintonia com a advertência do professor André Prous citada na introdução deste artigo, que dificilmente os dados coletados em sítios e analisados pela arqueologia para as populações pré-históricas ou anteriores ao contato com o conquistador europeu poderiam dizer alguma coisa sobre os grupos indígenas atuais, mesmo que estes ocupassem um território sobreposto ou contínuo ao sítio arqueológico estudado. De fato, dificilmente podemos pressupor uma continuidade entre essas duas unidades de estudo: o sítio arqueológico e a área etnográfica. Mas, nos últimos tempos, cada vez mais, as populações indígenas têm se apropriado de vestígios arqueológicos (pinturas rupestres, petroglifos, cerâmicas, material lítico) como marcadores de identidade e territorialidade. Ora, então, aparentemente, o interesse do arqueólogo por tais vestígios parece estar num patamar oposto àquele do indígena pelos mesmos vestígios: os primeiros enfatizam 
a descontinuidade entre o passado e o presente como pressuposto metodológico ou quiçá garantia de integridade científica; o segundo enfatiza a continuidade entre presente e passado como garantia de seu futuro.

No caso da área etnográfica que analisamos no presente artigo, e coincidente com um estudo de identificação e delimitação de uma terra indígena (Kaxuyana-Tunayana) que estávamos desenvolvendo de forma paralela à nossa pesquisa antropológico-arqueológica, os índios muitas vezes enfatizaram a relação de continuidade entre os grupos atuais e os seus antepassados por meio de vários argumentos: 1) ao fundar uma nova aldeia, um morador sempre escolhe o local onde, no passado, moravam os seus possíveis antepassados, lugar que é, nesta região, quase sempre de terra preta; 2) como hoje há uma tendência a fundar aldeias abaixo das cachoeiras, num lugar de mais fácil acesso para as cidades da região, os indígenas estão sempre a recuperar uma memória segundo a qual os seus antepassados moravam a jusante, isto é, nas proximidades de onde hoje se localizam as cidades de Oriximiná, Faro e Nhamundá (no entorno das quais há uma grande quantidade de vestígios arqueológicos) — e, ainda, estão a recuperar os nomes indígenas dessas cidades; 3 ) os petroglifos encontrados no leito ou nas margens dos rios são sempre associados aos ancestrais ou a algum evento mítico correspondente aos grupos indígenas atuais.

Claro que não usamos, no estudo de identificação e delimitação desta Terra Indígena, apenas a memória e os argumentos dos indígenas para justificar a área tradicionalmente ocupada, como, aliás, determina o artigo 231 da Constituição; a memória deles não valeria nada, não fosse a ocupação real (habitação permanente, locais de roça, caça, pesca, etc.) nos dias de hoje. Contudo, seria tão absurdo afirmar que há uma conexão direta e indiscutível entre os grupos indígenas atuais e os seus antepassados que habitavam a região em estudo (bacia dos rios Nhamundá e Trombetas) quanto dizer que não existe elo entre esses dois grupos de população - desprezando, ademais, a memória indígena, e deixando apenas falar ou fazendo falar os vestígios do passado. Aliás, se a antropologia, como dissemos na introdução deste artigo, tem necessariamente que "dialogar" e estudar "com" os indígenas, pensamos que uma arqueologia "com” os indígenas também é possível e desejável. E aqui, justamente, não estamos falando apenas de uma etnoarqueologia — definida por Poloni (2011:335) como "uma "ciência que busca alcançar conhecimento arqueológico através de estudos de cunho etnográfico" - ou, muito menos, de uma arqueologia que conta apenas com a informação e a mão de obra nativa, mas de uma arqueologia "com pessoas", que toma a memória e o saber nativo para fazer "outra" arqueologia, uma arqueologia 
entre outras (entre aquelas que almejam fazer — e fazem, legitimamente uma arqueologia não "com", mas "sobre" os humanos de outrora).

Pode parecer estranho finalizar um artigo assim, mas gostaríamos de fazê-lo a partir de um último exemplo, a pesquisa de doutorado em andamento de $\mathrm{Ca}$ mila Jácome, pelo curso de arqueologia da Universidade de São Paulo, que, no nosso entendimento, é um tipo de nova arqueologia em gestação. ${ }^{29}$ No início de 2014, verifiquei o trabalho de campo de Jácome, que organizava uma coleção de cerâmica depositada em sacos plásticos nas dependências da Secretaria de Cultura da cidade de Oriximiná. Esses sacos de cerâmica tinham sido recolhidos, na sua maioria, por técnicos do Instituto do Patrimônio Histórico e Artístico Nacional (IPHAN), a partir de uma "batida” nas casas de ribeirinhos da região, depois de uma informação de que vários deles tiravam objetos dos sítios no entorno de suas casas e no interior do município. A maior parte dos cacos de cerâmica não podia mais ser relacionada a seu contexto. Contudo, podia-se correlacionar formas, desenhos e composição material, entre outros aspectos estilísticos e técnicos. Numa primeira observação, mais superficial, rapidamente seria creditado um eixo de classificação (que a arqueologia tradicional geralmente faz) baseado no fato de as peças serem ou não zoomorfas.

Contudo, era nisso que consistia o trabalho de Camila Jácome: acompanhada de indígenas da etnia Waiwai, ela podia acrescentar dimensões (ocultas para ela mesma) daquele material. A começar, a partir da observação e do comentário desses indígenas, ela pôde mais facilmente precisar quais espécies animais estavam modeladas na peça, ou verificar se eram, na verdade, animais mitológicos (ou sem relação com animais reais). Foi possível, também de forma relativamente fácil, detectar os usos daqueles artefatos de barro. E, ainda, verificou que, dependendo da perspectiva (tridimensional) na qual o objeto fosse observado, podia a ele ser relacionado ora um animal, ora outro. Por exemplo, uma jarra usada para tomar uma bebida (provavelmente, cauim) podia ser vista, se tomada na perspectiva do "doador" da bebida, como imagem de um jabuti, mas, se tomada na perspectiva do "recebedor" (aquele que bebia), podia ser vista como a imagem de um urubu.

Ora, muito provavelmente, a arqueóloga Camila Jácome jamais poderia chegar a esse tipo de interpretação e classificação sem a colaboração intelectual dos indígenas. Talvez o mais interessante a ser observado sobre tal experiência é que os indígenas auxiliares nesse processo de conhecimento e classificação aspiravam um dia a se tornar arqueólogos de fato e não apenas colaboradores dos arqueólogos. Sem dúvida, sem que isso signifique de antemão que a arqueologia que eles porventura fizerem será melhor do que a arqueologia feita por não indígenas, 
isso será necessariamente outra arqueologia — talvez uma arqueologia mais útil a eles e tão ou mais útil e renovadora para a ciência quanto aquela que se fez e se faz normalmente na arqueologia acadêmica e de contrato.

Recebido em: 21 de agosto 2014

Aceito em: 01 de outubro de 2014

Ruben Caixeta de Queiroz é professor Associado II da Universidade Federal de Minas Gerais. Realiza pesquisa junto ao povo Waiwai desde 1994. Foi coordenador, junto com Andre Prous, do "Projeto de pesquisa Norte Amazônico: etnologia e arqueologia na calha do rio Trombetas e na região das Guianas (por uma abordagem integrada entre os sistemas sócio-cósmicos do presente e os vestígios materiais do passado)". Foi coordenador do Grupo de Trabalho que identificou e delimitou a Terra Indígena Trombetas-Mapuera. É co-editor da "Devires - Revista de Cinema e Humanidades" Contato: caixetadequeiroz@, gmail.com

\section{Notas}

1. Agradeço à professora Alcida Rita Ramos por ter me convidado a participar deste Seminário, e, posteriormente, pela leitura cuidadosa do presente paper. Da mesma forma, agradeço pela leitura crítica e sugestões que me fizeram Renata Otto e Camila Jácome.

2. Sobre o assunto da falta de propriedade na definição dos grupos sociais, conferir o já clássico texto de Roy Wagner (1974).

3. Pode-se bem compreender que as datações radio-carbônicas não são dados absolutos seja porque a categoria tempo também não é absoluta, seja porque o passado somente existe olhando-o a partir do presente, seja porque os vestígios humanos e não humanos (solo, animais, urnas, cerâmicas, ossos, vegetais etc.) no passado sofreram ações e transformações dos agentes humanos e não-humanos naquele dado momento ou no que lhes sucedeu na linha do tempo. 
4. Para se imaginar o absurdo que pode ser esse tipo de raciocínio - que aposta na continuidade ou na descontinuidade levadas às últimas consequências -, basta pensar que, de um certo ponto de vista epistêmico e genético, todos "nós” humanos ("índios e não índios") guardamos, ao mesmo tempo, uma relação de continuidade e de descontinuidade com nossos ancestrais e com o passado. O mesmo tipo de raciocínio vale para o elo que une "humanos" e "animais", e assim por diante.

5. E, infelizmente, há laudos arqueológicos muito pouco confiáveis que são usados exatamente para negar a continuidade de tais ocupações e, assim, legitimar o empreendimento que transforma ou suprime o sítio arqueológico e/ou negar a identidade originária de determinado grupo.

6. Citamos, a título de exemplo dessas exceções, as pesquisas em etnoarqueologia, entre as quais destacamos o pioneirismo no Brasil de Irmhild Wüst (1992), e os trabalhos atuais de Fabíola Silva (2012, 2013). Para citar outro caso, Schiavetto alerta no seu estudo sobre os Guarani: "não se trata de simplesmente desvincular cultura material e grupos étnicos, dizendo, por exemplo, que os Guarani pré-históricos nada têm a ver com os Guarani conhecidos ou com os actuais (...) Trata-se, ao contrário, de aceitar a possibilidade de os grupos étnicos serem vistos como entidades dotadas de um caráter situacional e fluído, repensando as tradições e subtradições utilizadas na arqueologia até o momento" (apud Poloni, 2011:335).

7. Estamos aqui, claro, simplificando a oposição entre antropologia e arqueologia, pois, da mesma forma que há muitas antropologias e não "uma" antropologia, há "muitas" arqueologias que são diferentes da arqueologia "padrão" ou "tradicional", por exemplo as communities archaeologies, as indigenous archaeologies e as "arqueologias colaborativas".

8. Como disse Neves (2012: 41): “o objeto de estudo da arqueologia tem natureza híbrida e é uma matriz de componentes naturais e culturais".

9. Do ponto de vista metodológico, supõe-se, não só a história de longa duração interessou e afetou a arqueologia, mas a micro-história a interessou igualmente a partir da "história das mentalidades", da percepção do tempo por diferentes sujeitos e dos micro-eventos.

10. Para precisar o ponto no qual Ingold (2008:82) vê a diferença entre a antropologia e outras ciências, tais como a história e a psicologia, podemos citar: "we may think we live in societies, but can anyone ever tell where their society ends and another begins? Granted that we are not sure what societies are, or even whether they exist at all, could we not simply say that anthropology is the study of people? There is much to be said for this, but it still does not help us to distinguish anthropology from all the other disciplines that claim to study people in one way or another, from history and psychology to the various branches of biology and bio-medicine. What truly distinguishes anthropology, I believe, is that it is not a study of all, but a study with. Anthropologists work and study with people. 
Immersed with them in an environment of joint activity, they learn to see things (or hear them, or touch them) in the ways their teachers and companions do".

11. Não há dúvida que, se este tipo de arqueologia com os "nativos" está apenas em fase embrionária, ela já levanta críticas contundentes à arqueologia de contrato e à "arqueologia padrão”. Veja, por exemplo, o recente caso de retirada de urnas de uma área de tradicional ocupação dos índios Munduruku (feita no contexto de uma arqueologia de contrato para um grande empreendimento) e a reação que isso desencadeou em parte da comunidade arqueológica, através de um documento que pode ser consultado aqui: http://racismoambiental.net.br/2013/06/arqueologia-pelas-gentes-um-manifesto-constatacoes-e-posicionamentos-criticos-sobre-a-arqueologia-brasileira-em-tempos-de-pac-imperdivel/

12. Conferir os trabalhos de Guapindaia (2008) e Hilbert \& Hilbert (1980).

13. Segundo informações de Frikel (1970:38), o Forte de Pauxis foi construído em 1697 pelo Capitão Manoel da Mota e Siqueira, por ordem do capitão-general e governador do Grão-Pará.

14. "Em 1693, com a redistribuição dos territórios missionários, a aldeia jesuítica de Santa Cruz do Jamundá (ou Nhamundá), junto ao baixo curso daquele rio, passou à gestão dos Capuchos da Piedade sob a denominação de São João Batista de Nhamundás (Leite, 1943, p. 277-278). Alguns anos mais tarde, a aldeia foi transferida para as margens do lago de Faro, de ares mais salubres e de melhor acesso, onde iria dar origem à cidade deste nome" (Porro, 2008:388).

15. De acordo com o relatório de São Manços (1903), as expedições comandadas por sua missão teriam subido até as cabeceiras do Rio Trombetas. Contudo, segundo Antônio Porro, a partir de Cachoeira Porteira, os missionários teriam seguido o curso do Rio Mapuera. Porro relativiza esse "equívoco" ao dizer que, obviamente, "ao denominar 'Trombetas' o Rio Mapuera, São Manços não estava cometendo um erro geográfico; o 'verdadeiro' curso de um rio tem sido, muitas vezes, mera convenção geográfica, e o 'verdadeiro' alto Trombetas ainda não era conhecido” (Porro, 2008:393). Além disso, na sua parte norte, o Rio Mapuera é formado pela confluência dos rios Tauini (margem direita) e Urucurim (margem esquerda). As cabeceiras deste último rio se aproximam das cabeceiras do Rio Cafuini, que é exatamente um afluente da margem direita do Rio Trombetas. Por meio desse interflúvio Urucurim-Cafuini, os grupos indígenas da bacia do Alto Mapuera comunicavam-se e tinham extensas relações com os grupos indígenas da bacia do Alto Trombetas. Ou seja, no final das contas, Alto Mapuera e Alto Trombetas situam-se numa mesma "área etnográfica”.

16. O termo "nação" usado nesse contexto e nessa época corresponde mais ou menos ao que, nos tempos atuais, alguns etnógrafos tendem a designar como "grupo étnico" ou "grupo local". Todos esses termos, conforme veremos, são insuficientes para descrever a complexa rede de fusão e dispersão das unidades sociais nessa região. 
17. Relativizemos aqui essa afirmação acerca da "autonomia" e "distância" das populações indígenas na área perante a presença dos colonizadores, pois temos informações, a partir da história oral, de que, além dos descimentos e aldeamentos indígenas promovidos por missionários jesuítas desde o final do século XVII, a região nunca deixou de ser explorada nos séculos subsequentes por gateiros, exploradores de madeira e outras "drogas do sertão", tais como castanha, cravo, puxuri, salsaparrilha e urucum. Note-se, contudo, que nessa área não houve um forte impacto destrutivo e desordenador das populações indígenas em função da exploração da borracha, como aconteceu noutras regiões da Amazônia.

18. Segundo a Wikipédia, a elite fazendária, ressentida pela falta de participação política no período regencial brasileiro, teria mobilizado tapuaias, cabanos, negros e índios contra a instalação do governo provincial do Grão-Pará. O poder central do país recém-independente, então, bombardeou impiedosamente Belém e promoveu um extermínio em massa da população paraense. Estima-se que de 30\% a 40\% da população de 100 mil habitantes do Grão-Pará tenha morrido no conflito. Dado o seu saldo de mortos exorbitante e a chacina de povos promovida pela coroa, a Cabanagem é um dos maiores conflitos já ocorridos na história do país.

19. Segundo as lembranças de um quilombola da comunidade Moura (Rio Trombetas), entrevistado por Funes (2004:13-14), “eles [os quilombolas] eram daí de fora. Vinheram prá cá corridos no tempo da cabanagem. Tudo isso por aqui era índio que vivia e a prova é que em todas essa terra por aí você encontrava figura de índio; daí eles pegaram de veras e vieram entrando, aí os índios também foram se afastando, foram carregando aí pra cima e eles vieram entrando e ficando".

20. Esse é o caso dos índios Mawayana, no Rio Urucurim, e dos índios Karapawyana, das cabeceiras do Rio Kikwo (ou Baracuxi), afluentes, respectivamente, da margem esquerda e da margem direita do Alto Rio Mapuera. Tais índios, quando contatados por missionários entre as décadas de 1950 e 1980, viviam de pequenas roças, com uso de machado de pedra, de caça e coleta, sem qualquer acesso a equipamentos industriais como machado de ferro e miçangas.

21. De forma resumida, queremos ressaltar, a partir dessa breve análise histórica, três pontos relevantes: 1) os índios do Alto Rio Nhamundá (hoje representados pelos Hixkaryana), do Alto Rio Mapuera (onde os Waiwai são a maioria, hoje) e do Alto Rio Trombetas (hoje representados pelos Katuena e Tunayana) teriam se formado da junção de grupos locais, relativamente autônomos, com aqueles que subiram a partir do sul e do baixo curso desses rios, fugindo das frentes de colonização portuguesa e brasileira, sobretudo, do final do século XIX e início do século XX; 2) ainda no século XIX, tais índios teriam sofrido com as investidas comandadas, a partir do norte, por ingleses e holandeses, que buscavam aprisionar indígenas como escravos; 3) do início até a metade do século XX, aproximadamente, tais índios mantinham contatos muito esporádicos e indiretos com as 
frentes de colonização inglesa e holandesa — que, por meio dos negros marrons, continuavam fazendo entrar bens industriais no território ocupado pelos indígenas; além disso, nesse período, eles tinham praticamente cessado o contato com as frentes colonizadoras ou missionárias de origem luso-brasileira que subiam os rios afluentes da margem esquerda do Médio-Baixo Rio Amazonas.

22. As lideranças indígenas e religiosas também obtiveram apoio da Força Aérea Brasileira (FAB), por intermédio do Brigadeiro Camarão, para a construção de uma pista de pouso no Médio Rio Mapuera e, também, daquela aldeia. O exército brasileiro tinha interesse em promover o regresso dos índios como estratégia de ocupação da fronteira brasileira e de defesa nacional.

23. Essa aldeia foi instalada nesse local por ser um ponto estratégico para atracar o barco de centro — que dali não pode mais subir o Rio Mapuera, devido às cachoeiras utilizado pelos índios para descer até a cidade de Oriximiná.

24. Apenas em fase inicial, o projeto coordenado por nós, Ruben Caixeta e André Prous, comentado anteriormente, pretende suprir em parte esta lacuna de uma arqueologia das cabeceiras do rio Trombetas. A dissertação de Jácome (2011) e a sua atual pesquisa de doutorado pela USP são desdobramentos deste projeto.

25. Isto não impossibilitou que, de forma muito rápida, depois do contato com outros grupos indígenas navegadores da região, esses índios "não navegadores" aprendessem e adotassem a técnica da navegação que utiliza a canoa de tronco de árvore (cavado e queimado, para adquirir formato da canoa). Tampouco podemos afirmar que, num passado mais longínquo — digamos, de 500 anos — os antepassados desses atuais grupos indígenas não tenham dominado a técnica da navegação e os recursos dos rios maiores.

26. Roosevelt (1993) para o Baixo Amazonas, Heckenberger (1996) para o Xingu, e Neves (2012) para a Amazônia Central.

27. E, a julgar pelos registros históricos, muito provavelmente, padrão de assentamento similar ao dos grupos que ocupavam esse mesmo território no início do século XVIII.

28. De fato, entre outros arqueólogos, Anna Roosevelt (1993 e 1994) criticava a visão da Amazônia como um ambiente natural que não possibilitava a formação de sociedades complexas (como no caso dos altiplanos). Contudo, Roosevelt parece insistir no contraste entre terra firme e várzea. Segundo Viveiros de Castro (2002:330), o modelo rooseveltiano "parece, às vezes, supor que o meio interfluvial [terra firme] era desabitado antes da invasão europeia (Carneiro 1995), o que é mais que improvável, ou, então, que todos os grupos que porventura ali viviam ou vivem seriam marginais alijados do paraíso fluvial _ como se houvesse um tropismo irresistível de toda sociedade, seja qual for seu regime de produção e reprodução sociais, em direção a áreas abstratamente mais férteis. O modelo, por fim, essencializa a distinção entre as chefaturas ripárias [...] e os sistemas sociais da terra firme, antigos ou contemporâneos. Seria mais avisado, considerando-se o substrato 
cultural comum a toda a Amazônia, imaginar uma dinâmica de tipo Gumsa/Gumlao (Leach 1954 [ver Santos 1993:226, para essa analogia na Amazônia atual]), sujeita a contrações e expansões conjunturais, articulando populações de várzea e de terra firme em sistemas regionais ecológica e sociopoliticamente heterogêneos" (grifo nosso).

29. Meu conhecimento sobre os estudos em arqueologia é limitado e, evidentemente, suponho haver muito mais experiências novas e tipos de arqueologias do que aquela aqui mencionada. Além do trabalho de Camila Jácome (2011), a partir do qual sua tese de doutorado está sendo uma continuação, gostaríamos de citar a tese de Raoni Vale (2012) e o trabalho de Mariana Petry Cabral (neste volume). Por fim, gostaria de remeter o leitor ao trabalho de Poloni (2011), uma boa síntese dos estudos em etnoarqueologia no Brasil contemporâneo.

\section{Referências bibliográficas}

ACEVEDO, Rosa \& CASTRO, Edna. 1993. Negros do Trombetas: guardiães de matas e rios. Belém: UFPA.

BALÉE, William. 1993. "Indigenous transformation of Amazonian forests: an example from Maranhão, Brazil”. In: Philippe Descola \& Anne Christine Taylor (eds.). La remontée de l'Amazonie: anthropologie et histoire des sociétés amazoniennes. L'Homme, 33(126-128):231-254.

CAIXETA DE QUEIROZ, Ruben. 2008. Trombetas-Mapuera: território indígena. Brasília: Funai/PPTAL.

CARNEIRO. Robert. 1995. "The history of ecological interpretations of Amazonia: does Roosevelt have it right?” In: L. Sponsel (ed.). Indigenous people and the future of Amazonia: an ecological anthropology of an endangered world. Tucson: University of Arizona Press. pp. 45-70.

CLASTRES, Pierre. 2003. A sociedade contra o Estado. São Paulo: Cosac Naify.

FAUSTO, Carlos \& HECKENBERGER, Michael (eds.). 2007. Time and memory in Indigenous Amazonia: anthropological perspectives. Gainnesville: University Press of Florida.

FRIKEL, Protásio. 1958. "Classificações lingüístico-etnológica das tribos indígenas do Pará setentrional e zonas adjacentes”. Revista de Antropologia, 1. 1970. "Os Kaxuyana: notas etno-históricas”. Publicações Avulsas (Museu Paraense Emílio Goeldi), 14. 
. 1971. "Dez anos de aculturação Tiriyó: 1960-70: mudanças e problemas”. Publicações Avulsas (Museu Paraense Emílio Goeldi), 16.

. 1972. "Elementos demográficos do Alto Paru de Oeste, Tumucumaque brasileiro: índios Ewarhoyána, Kaxúyana e Tiriyó”. Publicações Avulsas (Museu Paraense Emílio Goeldi), 19.

FUNES, Eurípedes. 2004. "Mocambos do Trombetas: história, memória e identidade". EAVirtual, 1(1):5-25.

GOLDMAN 2003. "Os tambores dos mortos e os tambores dos vivos. Etnografia, antropologia e política em Ilhéus, Bahia”. Revista de Antropologia, 46 (2):445-476.

GOMES, Denise M. C. 2013. "Metodologia da pesquisa arqueológica: uma introdução”. Boletim do Museu Paraense Emílio Goeldi (Ciências Humanas), 8(3):513-516.

GUAPINDAIA, Vera. 2008. Além da margem do rio: a ocupação Konduri e Poço na região de Porto Trombetas. Tese de Doutorado, Universidade de São Paulo.

GUAPINDAIA, Vera \& AIRES DA FONSECA, João. 2013. "Metodologia de delimitação no sítio arqueológico Cipoal do Araticum na região do rio Trombetas, Pará, Brasil”. Boletim do Museu Paraense Emílio Goeldi (Ciências Humanas), 8(3):657-673.

GUPPY, Nicholas. 1958. Wai-Wai: through the Forests North of the Amazon. London: John Murray.

HECKENBERGER, Michael. 1996. War and peace in the shadow of empire: sociopolitical change in the Upper Xingu of Southeastern Amazonia, A. D. 1250-2000. Tese de Doutorado, University of Pittsburgh.

HILBERT \& HILBERT 1980. "Resultados preliminares da pesquisa arqueológica nos rios Nhamundá e Trombetas, Baixo Amazonas.” Boletim do Museu Paraense Emílio Goeldi, Nova Série, Antropologia, 75: 1-11.

HOWARD, Catherine. 2003. Wrought Identities: the Waiwai Expeditions in Search of the "Unseen Tribes" of Northern Amazonia. Tese de Doutorado, The University of Chicago.

JÁCOME, Camila. 2011. Pelo Rio Mapuera: reflexões entre arqueologia e etnologia indígena na Amazônia e Guiana. Dissertação de Mestrado, Universidade Federal de Minas Gerais.

INGOLD, Tim. P. 2008. "Anthropology is not Ethnography”. Proceedings of the British Academy, 154:69-92.

LATHRAP. Donald. 1970. The upper Amazon. New York: Praeger. 
LEACH, Edmund. 1995. Sistemas políticos da Alta Birmânia. São Paulo: Edusp.

MEEGERS, Betty. 1971. Amazonia: man and culture in a counterfeit Paradise. Chicago: Aldine-Atherton.

NEVES, Eduardo Góes. 2012. Sob os tempos do equinócio: oito mil anos de história na Amazônia Central (6.500 AC - 1.500 DC). Tese de Livre Docência, Universidade de São Paulo.

PERRONE-MOISÉS, Beatriz \& SZTUTMAN, Renato. 2010. "Notícias de uma certa confederação Tamoio”. Mana, 16(2):401-433.

POLONI, Rita Juliana Soares. 2011. "A etnoarqueologia brasileira contemporânea: cultura material e implicações sociais”. Estrat Critic, 5(1):328-338.

PORRO, Antonio. 2008. "Notas sobre o antigo povoamento indígena do alto Trombetas e Mapuera”. Boletim do Museu Paraense Emílio Goeldi (Ciências Humanas), 3(3): 387-397.

RIVIÈRE, Peter. 1969. Marriage among the Trio: a Principle of Social Organization. Oxford: Clarendon Press; London \& New York: Oxford University Press.

1984. Individual and Society in Guiana: a Comparative Study of Amerindian Social Organization. Cambridge: University Press.

ROOSEVELT, Anna. 1992. "Arqueologia amazônica”. In: Manuela Carneiro da Cunha (org.). História dos índios no Brasil. São Paulo: Companhia das Letras/FAPESP/SMC. pp. 53-86.

1993. "The rise and fall of Amazonian chiefdoms”. In: Philippe Descola \& Anne Christine Taylor (eds.). La remontée de l'Amazonie: anthropologie et histoire des sociétés amazoniennes. L'Homme, 33(126-128):255-283.

1994. "Amazonian anthropology: strategy for a new synthesis”. In: Anna Roosevelt (ed.). Amazonian Indians from prehistory to the present. Tucson: University of Arizona Press. pp. 1-29.

SANTOS, Fernando. 1993. "From prisoner of the group to darling of the gods: an approach to the issue of power in lowland South America.” In: Philippe Descola \& Anne Christine Taylor (eds.). La remontée de l'Amazonie: anthropologie et histoire des sociétés amazoniennes. L'Homme, 33(126-128):213-230.

SÃO MANÇOS, Francisco de. 1903. "Rapport presenté au roi par le frère F. de São Manços, religieux de l'Ordre de la Pitié et missionaire dans le village des Nhamundás sur son voyage par la rivière Trombetas le 6.1.1728”. In: Barão Paranhos Rio Branco. Limites entre le Brésil et la Guyane Anglaise. Anexe au $1^{\circ}$ mémoire, 3:42-52. 
SILVA, Fabíola A. 2013. "Território, lugares e memória dos Asurini do Xingu”. Revista de Arqueologia (Sociedade de Arqueologia Brasileira), 26:28-41.

. 2012. “O plural e o singular das Arqueologias Indígenas". Revista de Arqueologia (Sociedade de Arqueologia Brasileira), 25:24-42.

STEWARD, Julian (org.). 1946-1950. Handbook of South American Indians. Washington: Smithsonian Institution. v. 1-6.

SZTUTMAN, Renato. 2009. "Religião nômade ou germe do Estado? Pierre e Hélène Clastres diante da vertigem tupi”. Novos Estudos CEBRAP, 83:129-157.

. 2012a. "Pensar com Pierre Clastres ou da atualidade do contra-Estado". Revista de Antropologia, 54:5-20.

. 2012b. "O contra o Estado e as políticas ameríndias: algumas meditações clastreanas”. In: Renarde Freire Nobre (org.). O poder em perspectiva. Belo Horizonte: Sografe. pp. 183-214.

VALE, Raoni. 2012. Mentes graníticas e mentes areníticas: fronteira geo-cognitiva nas gravuras rupestres do Baixo Rio Negro, Amazônia Setentrional. Tese de Doutorado, Universidade de São Paulo.

VIVEIROS DE CASTRO, Eduardo. 2002. “Imagens da natureza e da sociedade”. In: $A$ Inconstância da alma selvagem e outros ensaios de antropologia. São Paulo: Cosac Naify. pp. 319-344.

WAGNER, Roy. 1974. "Are There Social Groups in the New Guinea Highlands?" In: LEAF, Murray (ed.). Frontiers of Anthropology. Nova York: Cincinnati: Toronto: Londres: Melbourne: D. Van Nostrand Company. pp. 95-122. 1981. The invention of culture. Chicago: University of Chicago..

WÜST, Irmhild. 1992. “Contribuições arqueológicas, etnoarqueológicas e etno-históricas para o estudo dos grupos tribais do Brasil Central: o caso Bororo". Revista do Museu de Arqueologia e Etnologia, (2):13-26. 


\section{Resumo}

O artigo discute as possibilidades de colaboração entre etnologia e arqueologia, a partir de uma análise dos processos de formação, concentração e dispersão dos grupos indígenas do complexo cultural Tarumã-Parukoto (que hoje ocupam a região de fronteira entre Brasil, Guiana e Suriname). Nesta região da Amazônia e alhures, dificilmente podemos delimitar onde começa e termina as fronteiras de um grupo social ou étnico e, dessa forma, torna-se quase impossível fazer coincidir precisamente um determinado grupo étnico a um determinado território. Não passado e no presente, as fronteiras fluidas dos grupos, móveis no espaço e no tempo, revelam-se um desafio ainda maior para a perspectiva de trabalho em conjunto entre etnologia e arqueologia.

Palavras-Chave: Etnologia, Amazônia, Arqueologia, Guiana, Caribe.

\section{Abstract}

This article discusses the possibilities of establishing a working collaboration between Ethnology and Archaeology, based on an analysis of the processes of formation, concentration and dispersion of the indigenous groups that form the cultural complex known as TarumãParukoto (which today occupy the border region between Brazil, Guyana and Suriname). In this Amazon region and elsewhere, we can hardly define where the borders of a social or ethnic group begins and ends and thus it becomes almost impossible to match with precision a particular ethnic group to a particular territory. In the past and in the present, the fluid borders of groups, moving in space and time, prove to be an even greater challenge for a comparative perspective between Ethnology and Archaeology.

Keywords: Ethnology, Amazon, Archeology, Guyana, Carib Societies. 